\title{
A BLACK PARTY? TIMMONS, BLACK BACKLASH AND THE ENDANGERED TWO- PARTY PARADIGM
}

\author{
TERRY SMITH $\dagger$
}

\begin{abstract}
A BSTRACT
In a pair of 1997 electoral decisions, the Supreme Court decided that Minnesota could prohibit fusion candidacies in the interest of maintaining a strong two-party system, but that Georgia could not create two new majority-minority congressional districts because the redistricting process had been impermissibly infected by race. In this A rticle, Professor Smith argues that these two decisions unavoidably conflict. While the fusion case reaffirmed the states' interest in maintaining a strong two-party system, the racial gerrymandering case severely undercut the states' ability to achieve this interest in jurisdictions where the major parties are racially stratified. He demonstrates that blacks operating in a third party could constitutionally obtain the creation of majority-black congressional districts, a result that the Court has denied them when they act within one of the major parties. Professor Smith argues that such an anomaly encourages black exit from the two-party system. He argues that the Court's failure to insist on an injury to voting in the racial gerrymandering case makes it impossible for the Court to fashion relief that is consistent with states' interest in two-party stability.
\end{abstract}

$\dagger \quad$ A ssociate Professor of Law, Fordham U niversity School of Law. A.B. 1986, B rown U niversity; J .D. 1989, N ew Y ork U niversity School of L aw. M any thanks to Paulette Caldwell, R obert Chang, M argaret $C$ hon, $L$ inda $G$ reene, $D$ arren $H$ utchinson and $K$ aren Porter for their generous and influential comments on an earlier draft of this A rticle. A later draft benefited from the criticisms of George Cochran, Jill Fisch, L aughlin M CD onald and B arbara Phillips Sullivan. J ason A bramson provided excellent research assistance. 


\section{TABLE OF CONTENTS}

Introduction 2

I. The Two-Party System and A M odel of Party

Participation 9

A . The Two-Party System and the Problem of E quality......... 10

B. Timmons: The E lusive Q uest for T wo-Party Stability ....... 15

II. D eference D ue, D eference D enied: A brams v. J ohnson ...........22

A . B eyond B lack and W hite ..................................................23

B. Seeing O nly B lack and W hite ............................................27

III. The $D$ eference-I njury N exus: A $n$ I nitial I nquiry ..................... 42

A. A brams: W hat K ind of Injury? What K ind of

E quality?

B. A R emedy at What Price?: R acial Splintering of the

Two-Party Process

1. D istinctions B etween B lack and W hite Exit ...............59

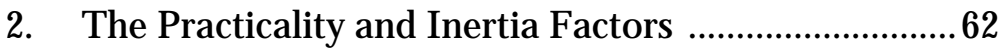

3. The Shifting Political E nvironment ............................ 65

IV . The Crossroads of Timmons and A brams: G reater Instability? 66

A . The Deference-Injury N exus: A Second L ook ..................67 67

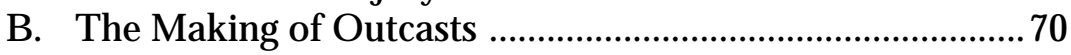

Conclusion

\section{INTRODUCTION}

In his essay "Notes For A Hypothetical Novel: A n A ddress," J ames Baldwin describes a compulsion to speak that would overcome all but the most impervious of human beings. The author writes of a friend who has just murdered his own mother and stowed her away in a closet. Baldwin knows what has just transpired, and more importantly, the friend is aware of Baldwin's knowledge. B oth men conspire to remain silent, to interact with each other as if all were normal, but Baldwin's conscience interferes with his attempt at feigned ignorance of the body's presence. Conversational paralysis sets in shortly because, as Baldwin writes, "we can't talk about anything be-

1. JA MES BALDWIN, N otes for a H ypothetical N ovel: A $n$ Address, in NOBODY KNOWS MY NAME 141 (1961). 
cause we can't talk about [the murder, the body]. No matter what I say I may inadvertently stumble on this corpse." ${ }^{2}$

The affliction that besets Baldwin's relationship with his murderous friend is, to Baldwin's mind, a metaphor for the "incoherence" of an A merican society that has steadfastly resisted performing the cathartic act of acknowledging the badges of its racist past. $^{3}$ On this score, the essay's symbolism captures not only the racially tense state of affairs that seems endemic to A merican society, but also the dysfunction that is its inevitable by-product. No facet of A merican life is immune from this race-induced stultification, but nowhere is it more visible than in A merican politics and in the constitutional constraints imposed on the body politic by the Supreme Court. In a pair of 1997 electoral decisions, the Court again demonstrated that it, too, is a prisoner of Baldwin's dilemma, for its attempts to homogenize A merican politics in these cases may, like the body in the closet of Baldwin's friend, have the unintended effect of accentuating fault lines-in this case racial.

In Timmons v. T win Cities A rea N ew Party, ${ }^{4}$ the Court addressed the right of a minor political party, the Twin Cities A rea New Party, to co-nominate a D emocratic candidate as its nominee for office. The New Party is a progressive one with a heavy minority membership. ${ }^{5}$ In upholding M innesota's ban on such "fusion" candidacies against the party's First A mendment freedom of association challenge, the Court reaffirmed the states' interest in ensuring political stability, even at the cost of favoring the two established major parties. ${ }^{6} \mathrm{~W}$ riting for a six-justice majority, Chief J ustice R ehnquist concluded that 'the States' interest permits them to enact reasonable election regulations that may, in practice, favor the traditional two-party system .... The Constitution permits the M innesota L egislature to decide that political stability is best served through a healthy two-party system." 7 Paradoxically, although the Court concluded that the need for two-party stability justified M innesota's ban on multi-party nomi-

2. Id. at 150 .

3. See id. at 150-53.

4. 117 S. Ct. 1364 (1997).

5. See J ack W. G ermond \& J ules W itcover, The Court Toasts the Two-P arty System, 29 NA T'L J 890 (1997) (reporting that the New Party consisted largely of union members, antipoverty workers, environmentalists and minority voters in approximately fifteen A merican cities).

6. See Timmons, 117 S. Ct. at 1374.

7. Id. 
nations, the fusion candidacy in this case would arguably have strengthened the Democratic Party as much as the New Party because receiving the co-nomination could have broadened the Democrats' base of support. In effect, then, despite the dramatic erosion of voter affiliation with the two major parties, ${ }^{8}$ the Court found that states could protect their two-party systems by turning away voters who are outside, and presumably alienated from, those systems.

A brams v. J ohnson ${ }^{9}$ marked the Court's second installment in a Fourteenth A mendment challenge to majority-minority congressional districts drawn in Georgia pursuant to the $\mathrm{V}$ oting $\mathrm{R}$ ights $\mathrm{A}$ ct of $1965 .{ }^{10} \mathrm{~A} s$ a result of an earlier Supreme Court decision invalidating a newly created majority-black congressional district, ${ }^{11}$ a lower court reconfigured two of G eorgia's three majority-minority districts, reducing the black population in each to below majority status and leaving the state with only one black district. ${ }^{12}$ The black voters who were parties to the suit responded that the lower court's redistricting improperly ignored the G eorgia legislature's intent to create at least two black districts, and that, to the extent that only one was maintained, the court's actions violated the $\mathrm{V}$ oting $\mathrm{R}$ ights $\mathrm{A}$ ct by diluting black voters' voting strength. ${ }^{13}$ In rejecting these claims, the Supreme Court found that Georgia's earlier redistricting plans containing two black districts did not reflect the will of the Georgia legislature since these plans had been forced upon the legislature by the $U$ nited States Department of Justice (DOJ), with the aid of the A merican Civil L iberties U nion (A CLU) and black voters and legislators. ${ }^{14}$ The Supreme Court also found that the black voters challenging the district court's substitute plan had not proven the requisite elements of a

8. See A lan Greenblatt, Politics and Marketing Merge in Parties' Bid for Relevance, CONG. Q. WKLY. REP., A ug. 16, 1997, at 1967, 1969 (reporting that a plurality of voters now identify themselves as independents rather than D emocrats or R epublicans). The phenomenon of voters separating themselves from political parties rather than switching affiliations from one party to another is known as "dealignment." See David G. LAWRENCE, The Colla PSE of the Democratic Presidential Majority: Realignment, Dealignment, and Electoral Change from Franklin Roosevelt to Bill Clinton 21 (1996).

9. 117 S. Ct. 1925 (1997).

10. See id. at 1929

11. See M iller v. J ohnson, 515 U .S. 900 (1995).

12. See A brams, 117 S. Ct. at 1929-30 (citing J ohnson v. M iller, 922 F. Supp. 1556 (S.D . Ga. 1995)).

13. See id. at 1930

14. See id. at 1931. 
vote dilution claim. ${ }^{15}$ Ironically, these voters would not have had to prove vote dilution if the Court had simply required implementation of the earlier redistricting plans that had won majorities in both houses of the G eorgia legislature. ${ }^{16}$ The Court dismissed these earlier plans largely because black voters, with the aid of the government and the ACLU, had successfully persuaded the State of G eorgia to enact them. ${ }^{17} \mathrm{U}$ nder the rule of $\mathrm{A}$ brams, then, legislation may become constitutionally tainted because the group seeking the legislation identifies its political interests through the prism of race. A s the Court had earlier stated, sanctioning black group identity politics in redistricting would "bear[] an uncomfortable resemblance to political apartheid." 18

On first reading, Timmons, a First A mendment challenge to $M$ innesota's anti-fusion laws, and $A$ brams, a racial gerrymandering decision, are an unlikely jurisprudential pairing. $Y$ et their parallels, and their ultimate antagonism, are as significant as they are subtle. A s for their common ground, in both cases the Court denied a disfavored political minority equal access to the two-party system on the erroneous assumption that an accommodation of their interests would harm the political process. A s for the conflict between the two cases, Timmons and A brams collide at the ballot box. While Timmons purported to reaffirm states' interest in maintaining political stability through a strong two-party system, A brams severely undercut states' ability to achieve this interest in jurisdictions where the major parties are racially stratified.

U nder the Court's disjointed ballot-box jurisprudence, the First A mendment permits a state to employ the mantra of two-party stability to strip a minor party of its most cherished function- the nomination of the candidate of its choice-merely because the same candidate has also been nominated by a major party. A bsent exceptional circumstances, however, the Fourteenth A mendment prohibits a state from intentionally creating majority-minority districts, even

15. See id. at 1936. These elements are: "[F ]irst, the minority group 'is sufficiently large and geographically compact to constitute a majority in a single-member district'; second, the minority group is 'politically cohesive'; and third, the majority 'votes sufficiently as a bloc to enable it ... to defeat the minority's preferred candidate.'" Id. (quoting Thornburg v. Gingles, 478 U .S. 30, 50-51 (1986)).

16. See id. at 1943 (Breyer, J., dissenting) (stating that both the dissent and majority agreed "that the District Court should have drawn boundaries so as to leave two majorityminority districts rather than one-unless there was no such state policy or preference").

17. See id at 1931-34; see infra text accompanying notes 153-155.

18. Shaw v. R eno, 509 U.S. 630, 647 (1993). 
though the creation of such districts may enhance two-party stability by integrating into the political mainstream racial minorities who might otherwise join the ranks of the $\mathrm{N}$ ew Party or similar minor parties. Moreover, Timmons' foreclosure of fusion candidacies encourages racial minorities to break with the two-party process in an extremely destabilizing manner, for states may now force minor parties to register their preferences (and maintain their existence) by running against major party candidates rather than forming ad hoc coalitions with them. The consequent splintering of the electorate, potentially along racial lines, is far more destabilizing to the body politic than an accommodation of the outsiders' interests in Timmons and A brams would have been.

$R$ acial splintering of the two-party system is not a hypothetical musing. The Court has largely acceded to the states' identification of their two-party systems with political stability, ${ }_{19}$ and coalitional disincentives like those created by the Court's holdings in Timmons and A brams can certainly adversely affect two-party political stability. Such disincentives feed a budding backlash against a two-party system that minority voters believe has taken them for granted. A pproximately half of all A frican-A mericans support the formation of a separate black political party, ${ }^{20}$ while $\mathrm{H}$ ispanics express a comparable level of support for a third party. ${ }^{21} \mathrm{G}$ eorgia's redistricting experience after the remand of Miller v. Johnson, ${ }^{22}$ the forerunner to A brams, foreshadows how the Court's ballot-box jurisprudence threatens to tap into this disenchantment and unhinge the two-party process. When the Georgia Senate proposed a redistricting plan that contained only one black congressional district, Congresswoman Cynthia M cK inney, whose majority-black district would ultimately be reconfigured, led a coalition of blacks calling for the formation of a black third party. ${ }^{23}$ McK inney said through a spokesman that "[black

19. See infra notes $32-43$ and accompanying text.

20. See Clarence Page, White A merica Singing Bad-Times Blues, H OU S. CHRoN., O ct. 14, 1996, at 26. A mong young A frican-A mericans, more than $65 \%$ support the formation of an independent third party. See Lenora Fulani, Commentary, Blacks N eed To L eave D ems, G OP Behind, U SA TODAY, Sept. 6, 1996, at 11A.

21. See Tom Wicker, Deserting the Democrats: Why A frican-A mericans and the Poor Should M ake Common Cause in Their O wn Party, NA TION, J une 17, 1996, at 11 (reporting that $54 \%$ of $\mathrm{H}$ ispanics support the formation of a third party).

22. 515 U.S. 900 (1995).

23. See Benjamin Sheffner, J ust O ne Black D istrict Included in Ga. Remap, R OLL CALL, Sept. 7, 1995, available in LEXIS, N ews Library, R ollcl File; see also M arlon M anuel, G eorgia Blacks Consider Third Party; Democrats May Defect If Senate Map Adopted, A TLANTA 
D emocrats] feel they are being pushed out (and) used as spare parts to bolster the political fortunes of white D ixiecrats." ${ }^{24} \mathrm{G}$ eorgia's legislature ultimately deadlocked on the proposed redistricting and passed responsibility to the district court. ${ }^{25}$ That court imposed a plan similar to the one that had prompted black leaders to call for mass defection from the Democrats. ${ }^{26}$ The potential backlash against this plan appears to have been forestalled by M cK inney's reelection in a majority-white district, as well as by the reelection of Sanford Bishop, another black representative whose majority-black district was undone by the court's ruling. ${ }^{27}$ But how will black voters respond when the trappings of incumbency are no longer present and the white electorate in M CK inney's and Bishop's districts reverts to historical practice and votes against black and black-supported candidates? ${ }^{28}$

This A rticle explores the contentious relationship between race, political affiliation and political stability. It argues that the Supreme Court has induced political instability by failing to fashion a coherent ballot-box jurisprudence that accommodates outsiders' efforts to be included in the political mainstream, namely the established twoparty system. This lack of coherence largely stems from the Court's insistence on color-blindness in politics, but even when race neutrality has not been the impetus for its decisions, the Court has failed to

Const., Sept. 4, 1995, at C1 (reporting Congresswoman M CK inney's statements that if only one of three black congressional districts were retained, the formation of a third party would be "a very serious possibility").

24. Sheffner, supra note 23 .

25. See J ohnson v. Miller, 922 F. Supp. 1556, 1559 (S.D. G a. 1995).

26. See id. at 1568 .

27. See Christopher Weems, G eorgia's Congressional Districts Still In U proar, A TLA NTA INQUIRER, Dec. 28, 1996, at 1 (reporting the reelections of MCK inney and Bishop from redrawn, majority-white districts).

28. Prior to the creation of G eorgia's predominantly black Second and Eleventh congressional districts, only $1 \%$ to $4 \%$ of white voters in the precincts within these districts voted for minority candidates in statewide elections. See Laughlin MCD onald, Can Minority Voting Rights Survive M iller v. J ohnson?, 1 M ICH . J. R A CE \& L. 119, 140 (1996). A Ithough M CK inney and $B$ ishop were reelected in their post-A brams districts, there was substantial racial bloc voting in their elections. M CK inney took only an estimated 31\% of the white vote. See K evin Sack, Victory of 5 Redistricted B lacks Recasts G errymandering D ispute, N.Y. TIM ES, N ov. 23, 1996, at A 1. Bishop carried an estimated $36 \%$ of the white vote in his redrawn district. See id. J ohn F. K ennedy School of G overnment Professor K eith Reeves has concluded that M cK inney's and $B$ ishop's incumbency status in their former districts, and their concomitant fundraising advantages, accounted for their reelection victories in the redrawn, majority-white districts. See Keith ReEVes, Voting Hopes OR Fears?: White Voters, Black Candidates \& RaCial POLITICS IN A MERICA 109 (1997). Professor R eeves concurs with Representative M cK inney's assessment of her reelection: "The real test of whether majority-minority districts are still necessary will come from the minority candidates who vie for this seat after me." Id. at 110. 
perceive the unique consequences that its decisions have on racial minorities. Timmons and A brams, individually and collectively, illustrate the Court's misguided treatment of outsiders' attempts to access the political mainstream. Moreover, these cases illustrate the corrosive effect that the Court's failure to respond effectively to such attempts has on political stability-the very thing it is trying to protect.

The question-the accommodation of outsiders-can properly be framed as one concerning when and to what degree courts should defer to legislatures' political judgments about who should participate in the political process and on what terms. This, of course, is the classic judicial dilemma of the "political thicket." 29 Timmons and A brams add a new dimension to this problem because the Court's incursion into the political process in these cases encourages involuntary exit from the two-party system (a system states may legitimately prefer) by political factions (racial minorities) whose integration the Court purportedly desires.

This A rticle proceeds in four parts. Part I sets forth the historical and theoretical bases for the Court's sanction of a two-party political process and extracts a model of party participation against which Timmons and Abrams can be assessed. This section then presents Timmons as an example of how the Court is unable to intelligibly address outsiders' demands to participate in the two-party paradigm. Finally, Part I suggests a parallel between the Court's treatment of the New Party in Timmons and its curtailing of black aspirations of representation in A brams. Part II examines A brams more fully and argues that its holding disadvantages racial minorities with respect to a central activity in the two-party system-redistricting-and thus encourages less fidelity to that system. Part III argues that the Court's failure to insist on an injury to voting before granting relief in cases like $A$ brams renders it unable to fashion relief that is consistent with states' interest in two-party stability. Far from maintaining twoparty stability, recognizing claims that seek the dismantling of majority-black districts may well cause racial splintering of the two-party process by encouraging blacks to seek through an independent party what they have been denied as racial minorities within a major party. Part IV extends the injury-to-voting analysis to Timmons. It argues that the injury to the plaintiffs in Timmons was considerably more concrete than that suffered by the plaintiffs in Abrams, while the

29. Colegrove v. G reen, 328 U .S. 549, 556 (1946) (invoking the phrase to warn of the hazards of judicial intervention in districting matters). 
Court's intervention was incommensurately meager. M oreover, it argues that the Court's heightened concern about state-created racial categorizations cannot justify its lesser concern with the N ew Party's injury, since the New Party itself has a substantial minority membership and asserted a claim based on the fundamental right of its members to nominate the candidate of their choice. Part IV next explores the intersection of A brams and Timmons, arguing that the Court has misapprehended the spectrum of activities by which individuals (racial minorities in particular) might participate in the two-party system and that the combined effect of these cases is to drive racial minorities to the exclusionary point on the continuum. The A rticle concludes that the Court must acknowledge the racial dimension of twoparty stability and must apply a redefined conception of political stability to racial gerrymandering decisions such as A brams.

\section{The TWO-Party Sy Stem AND A M Odel of Party PARTICIPATION}

In order to appreciate the potential for a black apostasy of the two-party system, it is critical to comprehend the precepts of that system. M aintenance of a two-party system requires incentives to affiliate with the major parties and disincentives to avoid such affiliation. This presents a three-dimensional problem of equality. First, courts must define a principle for allocating political power between the major parties. Second, courts must assess the constitutionality of barriers to entry intended to prevent outsiders- minor parties like the $\mathrm{N}$ ew Party in Timmons $\mathrm{s}^{30}$ - from competing against and ultimately invading the province of the two-party duopoly. O utsiders, however, can also exist within a major party as a disempowered pressure group or "satellite party" that seeks to influence the party's position on a range of policy issues. Thus, the third issue that courts must consider is the allocation of power to factions within the major parties-lest

30. Timmons v. Twin Cities A rea N ew Party, $117 \mathrm{~S}$. Ct. 1364 (1997). In the course of the litigation, the New Party and its proponents advanced a "pressure-group" conception of third parties, emphasizing the role of minor parties in communicating policy preferences rather than defeating major-party candidates. See J ames G ray Pope, Fusion, Timmons v. T win Cities A rea New Party, and the Future of Third Parties in the United States, 50 RUTGERS L.J. 473, 491 (1998). A the same time, however, the New Party had hoped to use fusion to become a new major party. See id. at 502. A lthough the New Party's dual aspirations tend to blur the distinction between the equality claims of minor parties and pressure groups within major parties, "historical evidence suggests that institutionalization through fusion tends to submerge third party identities into those of their major party allies, thereby aborting third party challenges." Id. at 504. 
such factions exit and form third parties. The black voters in A brams essentially fall into this third category. ${ }^{31}$

The three prongs of the equality trilemma are interdependent. The principles of equality set forth in the first inform the expectations of outsiders like the N ew Party and black voters. To the extent that those expectations are disappointed, these outsiders are encouraged to exit the two-party paradigm, which may pose a more potent challenge to two-party stability than would the accommodation of their interests.

This Part begins by discussing the two-party model of political participation that the Supreme Court appears to have embraced in its ballot-box jurisprudence. The focus then shifts to Timmons, which illustrates the difficulty the Court has had including outsiders in its conception of two-party politics. This Part concludes by introducing the parallel between the Court's misapprehension of the outsiders' claims in Timmons and its restrictions on the partisan activities of black voters in A brams.

\section{A. The Two-P arty System and The P roblem of E quality}

The Constitution does not mention political parties. Y et, through its First A mendment and equal protection jurisprudence, the Supreme Court has given constitutional sanctity to the A merican two-party system. The constitutionalization of the two-party system has derived, in part, from minor-party efforts to dislodge it. The Supreme Court, recognizing the states' interest in maintaining the stability of their political systems against the potential splintering of the electorate, has sustained the constitutionality of state laws imposing strict requirements on minor parties attempting to gain access to the ballot. ${ }^{32}$ Similarly, the Court has upheld state efforts to limit inde-

31. A brams v. J ohnson, 117 S. Ct. 1925 (1997). B lacks' formal affiliation with either of the two major parties has historically been accompanied by the formation of parallel or satellite parties to force the major party to address issues of black oppression. See H A NES WA LTON, JR., Black Political PaRties 80-81 (1972) [hereinafter Walton, Black POlitical PaRTies]. The distinction between this practice and the pressure-group model of fusion is one of degree rather than kind.

32. See, e.g., M unro v. Socialist W orkers Party, 479 U .S. 189 (1986) (approving W ashington's requirement that a minor party receive at least $1 \%$ of the votes in a blanket, all-party primary in order to appear on the general election ballot); A merican Party of Texas v. White, 415 U .S. 767, 782 (1974) (upholding Texas's 1\% petition signature requirement for minor parties in light of "the State's admittedly vital interests ... that political parties appearing on the general ballot demonstrate a significant, measurable quantum of community support"); J enness v. Fortson, 403 U .S. 431 (1971) (upholding G eorgia's requirement that minor party candidates 
pendent candidates' access to the ballot by requiring such candidates to have disaffiliated from major parties. ${ }^{33}$ In sanctioning such a provision, the Court stated:

[S]plintered parties and unrestrained factionalism may do significant damage to the fabric of government. It appears obvious to us that the ... disaffiliation provision furthers the State's interest in the stability of its political system. We also consider that interest as not only permissible, but compelling and as outweighing the interest the candidate and his supporters may have in making a late rather than an early decision to seek independent ballot status. ${ }^{34}$

Courts have employed the Equal Protection Clause to institutionalize the two-party system by rejecting challenges to Democratic and R epublican state legislatures' gerrymandering to protect incumbents, ${ }^{35}$ by permitting the drawing of legislative lines which reflect each party's relative proportion of the electorate, ${ }^{36}$ and even by allowing one party to dilute the voting strength of the other disproportionately. ${ }^{37}$

The Court sees its preference for a two-party political system as being distinctly Madisonian. The multiplication of political parties implicates J ames M adison's admonition in The Federalist No. 10 that "the causes of faction" - a term M adison equated with political parties- "cannot be removed, and that relief is only to be sought in the means of controlling its effects." ${ }^{38}$ A ccording to M adison, those ef-

collect the signatures of $5 \%$ of the prior year's electorate in order to be placed on general election ballot). See also Terry Smith, N ote, Election L aw: Election L aws and First A mendment Freedoms-Confusion and Clarification by the Supreme Court, 1988 A N N. SU R V. A M . L. 597, 616-23 (critiquing the Court's ballot access decisions).

33. See Storer v. Brown, 415 U .S. 724 (1974) (upholding California's one-year disaffiliation requirement).

34. Id. at 736 (citations omitted)

35. See generally K risten Silverberg, N ote, The Illegitimacy of the Incumbent G errymander, 74 TEX. L. REV. 913 (1996) (criticizing the courts' general acquiescence to the incumbent gerrymander).

36. See $G$ affney v. Cummings, 412 U .S. 735, $752-54$ (1973) (upholding this practice).

37. See D avis v. B andemer, 478 U .S. 109, 133 (1986) (reversing a district court's finding of unconstitutional partisan gerrymandering because "such a finding of unconstitutionality must be supported by evidence of continued frustration of the will of a majority of the voters or effective denial to a minority of voters of a fair chance to influence the political process"). While $D$ avis is a sword for the two major parties to employ against each other, it is likewise a shield against the minor parties' claims that the Democrats and R epublicans have unfairly enshrined their parties at the expense of fledgling third parties.

38. The Federalist No. 10, at 57 (J ames Madison) (R obert B. L uce ed., 1976). See also Storer v. Brown, 415 U .S. 724, 736 (1974) (citing Federalist No. 10 in approving California's 
fects include "unsteadiness and injustice." ${ }^{39}$ Commentators, too, have hailed two-party politics as "a politics of coalition and accommodation rather than of ideological and charismatic fragmentation," which ensures that "there are few irreconcilable losers, and that the winners can govern." ${ }^{40}$

Perhaps no recent statement by a member of the Court more forcefully extols two-party stability than Justice O'Connor's pronouncement in Davis v. B andemer, ${ }^{41}$ a case in which the Court recognized a cause of action for partisan gerrymandering but announced a highly restrictive standard of proof. ${ }^{42} \mathrm{~A}$ ccording to J ustice $\mathrm{O}$ 'C onnor:

There can be little doubt that the emergence of a strong and stable two-party system in this country has contributed enormously to sound and effective government. The preservation and health of our political institutions, state and federal, depends to no small extent on the continued vitality of our two-party system, which permits both stability and measured change. The opportunity to control the drawing of electoral boundaries through the legislative process of apportionment is a critical and traditional part of politics in the U nited States, and one that plays no small role in fostering active participation in the political parties at every level. ${ }^{43}$

argument that its disaffiliation statute prevented "splintered parties and unrestrained factionalism"). A s a matter of constitutional history, the Court may be mistaken in ascribing its preference for two-party political stability to M adison. M adison's vision of politics was pluralist and advocated the existence of several political parties in order to prevent majority tyranny. See N ote, The Supreme Court, 1982 Term, 97 H A R V. L. R EV. 70, 158-59 (1983). B ut see Lloyd N. Cutler, Now Is The Time for All Good Men ..., 30 WM. \& MARY L. REV. 387, 389 (1989) (arguing that "faction," as M adison understood the term, "would not appear to cover a broadly based national political party that cuts across narrow interest groups").

39. THE FEDERALIST No. 10, supra note 38, at 54.

40. Alexander M. Bickel, Reform and Continuity 22 (1971). But see Richard L. $\mathrm{H}$ asen, E ntrenching The D uopoly: Why the Supreme Court Should N ot A llow the States to Protect the D emocrats and Republicans from Political Competition, 1997 SU P. CT. R EV. 331, 356-58 (noting the circularity of defining political stability in terms of whether more than two parties exist and arguing for a more empirical definition); Note, supra note 38, at 162 ("A merican political stability does not depend on a two-party oligopoly. The experience of other W estern societies and historical experience in this country demonstrate that minor parties and independent candidacies are compatible with long-term political stability.") (footnotes omitted).

This A rticle is agnostic on the question of whether the Supreme Court is empirically correct in its predictions of the unstable consequences of a multi-party system. H owever, an understanding of why the Court has embraced two-party politics is essential to a determination of whether the Court has acted rationally to facilitate the existence of such a system, particularly in a multi-racial polity. The latter question is the focus of this A rticle.

41. 478 U.S. 109 (1986)

42. See infra note 45 and accompanying text.

43. D avis, 478 U .S. at $144-45$ ( 0 'Connor, J ., concurring). 
D avis illustrates the intersection of two fundamental issues in A merican politics and jurisprudence: the degree to which the Constitution tolerates partisan hegemony and the meaning of the right to vote. In Davis, Indiana Democrats complained that a reapportionment plan enacted by $R$ epublicans unfairly disadvantaged $D$ emocrats in state legislative elections. ${ }^{44}$ W hile finding that the plan intentionally discriminated against D emocrats, the Court nevertheless upheld its validity:

$[T$ ]he mere fact that a particular apportionment scheme makes it more difficult for a particular group in a particular district to elect the representatives of its choice does not render that scheme constitutionally infirm. This conviction... stems from a perception that the power to influence the political process is not limited to winning elections.

$\cdots$

... [T ] he question is whether a particular group has been unconstitutionally denied its chance to effectively influence the political process .... In this context, such a finding of unconstitutionality must be supported by evidence of continued frustration of the will of a majority of the voters or effective denial to a minority of voters of a fair chance to influence the political process. ${ }^{45}$

The Indiana Democrats could not meet this onerous standard because their proof consisted primarily of the results of one election in which the number of seats obtained by Democrats was disproportionately low in comparison to the statewide vote for Democratic candidates. $^{46}$

The claim of the plaintiffs in D avis was one of protective democracy - that is, Indiana D emocrats maintained that they possessed inadequate political influence. ${ }^{47}$ The Court's treatment of that claim, however, relied on notions of formal equality, a theoretical parity

44. See id. at 115 .

45. Id. at 131-33.

46. See id. at 134-35.

47. See id. at 115. See generally J ames A . G ardner, L iberty, Community and the Constitutional Structure of Political Influence: A Reconsideration of the Right to Vote, $145 \mathrm{U}$. PA. L. REV. 893, 942 (1997) ("The essence of a protective democracy-based voting rights claim is a claim of inadequate political influence. The claimant says, in effect, ' $M$ y ability to influence the political process is inadequate; as a consequence, I am unable adequately to protect my rights and liberties.'"). 
that is presumed to flow from the equal access to the ballot. ${ }^{48} \mathrm{~A} s$ the Court concluded:

A $n$ individual or a group of individuals who votes for a losing candidate is usually deemed to be adequately represented by the winning candidate and to have as much opportunity to influence that candidate as other voters in the district. We cannot presume in such a situation, without actual proof to the contrary, that the candidate elected will entirely ignore the interests of those voters. This is true even in a safe district where the losing group loses election after election. ${ }^{49}$

The Davis majority harbored a romanticized view of politics. If we could reasonably presume that the prevailing party would adequately represent losers, then the very raison d'etre for parties would evaporate. Moreover, if "the power to influence the political process is not limited to winning elections," ${ }^{50}$ there is little reason for deferring to redistricting schemes, like the one in D avis, that enable a particular political party to do just that. It seems, then, that the Court's tolerance of mere formal equality ends where erosion of the twoparty system might begin. Some voters (members of the majority party) are entitled to substantive equality as a reward for successful participation in the party system:

[W]e think it most likely that whenever a legislature redistricts, those responsible for the legislation will know the likely political composition of the new districts and will have a prediction as to whether a particular district is a safe one for a Democratic or R e-

48. Formal equality requires a symmetry of treatment among individuals regardless of their race, sex or other "morally irrelevant" characteristics. Michael W. M cConnell, The Importance of H umility in J udicial Review: A Comment on Ronald D workin's 'M oral Reading' of the Constitution, 65 F OR D H A M L. REV. 1269, 1282 (1997). See also Paul Butler, A ffirmative A ction and the Criminal L aw, 68 U. Co LO. L. REV. 841, 873 (1997) (noting that formal equality in the criminal context means affording defendants the same degree of protection, regardless of differences in the severity of the potential punishment). In the voting context, the "one person, one vote" principle is an illustration of formal equality. See Gary Goodpaster, Equality and Free Speech: The Case against Substantive E quality, 82 I ow A L. REV. 645, 649 (1997). Formal equality is distinct from substantive equality, a concept which, like protective democracy, focuses on equality of outcomes. See id. at 646; J ane R utherford, E quality as the Primary Constitutional Value: The Case for Applying Employment Discrimination Laws to Religion, 81 CORNELL L. REV. 1049, 1072 (1996).

49. D avis, 478 U .S. at 132.

50. Id. 
publican candidate.... The reality is that districting inevitably has and is intended to have substantial political consequences. ${ }^{51}$

Thus, the lynchpin of the two-party process is the effort to control the allocation of partisan representation.

J ustice $\mathrm{O}$ 'Connor's concurrence refines this point. It-and to a lesser extent the majority's holding-can be interpreted as a functional approach to participation in the two-party process, one that neither fully embraces formal equality nor totally rejects protective democracy. In highlighting the importance of participating in the reapportionment process as an incentive for involvement in the twoparty system, J ustice $\mathrm{O}^{\prime} \mathrm{C}$ onnor acknowledges that party affiliation, and by extension voting, is instrumental. In other words, formal equality is insufficient; voters are rightly concerned with outcomes, for representation is a scarce resource. Her concurrence admits still more: if influencing the redistricting process is an incentive to participate in the two-party system, a lack of influence is, by negative implication, a disincentive to do the same. The question for the Court is, when will an overreliance on precepts of formal equality prevent states from achieving the very goal-political stability through maintenance of a two-party system-that the Court has encouraged them to seek? The model of party participation that one might reasonably derive from the Court's embrace of two-party political stability and its uneasy containment of protective democracy is that the Court must balance formalism against claims of substantive equality to fit the needs of the two-party system. A formalistic jurisprudence that creates significant incentives to exit the two-party process (particularly by groups which lend it continuing vitality) is fundamentally at odds with the concept of two-party stability and, by extension, with the Court's concept of modern democracy.

\section{B. Timmons: The E lusive Q uest for T wo-Party Stability}

It is a short leap from the rejection of a major party's claim for substantive equality in Davis v. Bandemer to judicial skepticism about equality claims by minor political parties. In their simplest form, such claims seek access to the ballot in order to compete against the major parties. ${ }^{52}$ In their more complex incarnation, however, the minor party seeks access to the two-party system in order to

51. Id. at 128-29 (citations and internal quotation marks omitted).

52. See, e.g., M unro v. Socialist W orkers Party, 479 U .S. 189 (1986). 
align itself with a like-minded, major-party candidate and thereby influence policy outcomes. Timmons involved a minor party in this latter situation. ${ }^{53}$ Like D avis, Timmons exposed the friction that inheres in a duopolistic model of party participation which presupposes that someone must lose but which also assumes that even the loser must retain a measure of substantive equality to discourage exit from the two-party paradigm.

In Timmons, the New Party, a liberal, multi-racial third party, sought to co-nominate Andy Dawkins, the Democratic-FarmerLabor ("D emocratic") standard bearer, for a seat in the M innesota state legislature. U nder the proposed arrangement, to which neither Dawkins nor the M innesota Democratic Party objected, Dawkins would appear as the nominee of both the Democratic Party and the N ew Party. ${ }^{54} \mathrm{M}$ innesota, however, prohibits such fusion candidacies. ${ }^{55}$ Because Dawkins had already filed a nomination petition as the nominee of the D emocratic Party, local election officers refused the nominating petition of the New Party. ${ }^{56}$ The New Party sued in federal court, contending that the state's ban abridged its associational rights. $^{57}$

A nti-fusion laws like $M$ innesota's are an outgrowth of late nineteenth century efforts by then-dominant R epublicans to scuttle coalitions between $D$ emocrats and minor political parties. ${ }^{58}$ The effect of such laws was to reduce the number and diminish the significance of third parties, many of which had thrived by virtue of fusion. A s one scholar has noted, minor political parties which had previously formed electoral coalitions with Democrats tended to be subsumed under the D emocratic Party banner after anti-fusion legislation became prevalent:

53. See Timmons v. Twin Cities A rea N ew Party, 117 S. Ct. 1364, 1367-68 (1997).

54. See id. at 1368.

55. See M INN. STA T. § 204B.04, subd. 2 (1998) ("No individual who seeks nomination for any partisan or nonpartisan office at a primary shall be nominated for the same office by nominating petition...."). Fusion is also referred to as "multiple party nomination" or "crossfiling." See William R. K irschner, Note, Fusion and the A ssociational Rights of M inor Political Parties, 95 Colum . L. REV . 683, 683 (1995).

56. See Timmons, $117 \mathrm{~S} . \mathrm{Ct}$. at 1368.

57. See id.

58. See Peter H. A rgersinger, "A Place on the Ballot": Fusion Politics and Antifusion L aws, 85 A M. H IST. REV. 287, 289-90 (1980) ("By offering additional votes in a closely divided electorate, fusion became a continuing objective not only of third party leaders seeking personal advancement or limited, tangible goals but also of $D$ emocratic politicians interested in immediate partisan advantage."). 
B ecause the adoption of a new composite name left the D emocratic name, with all of its appeal and tradition, to be used by minority factions ... because of even more grotesque ballot complications under the laws of some states, or merely because their greater national strength gave them an advantage in all electoral contests, the D emocrats were ultimately able to insist successfully that the name 'D emocrat' be adopted by all fusionists.

Thus, anti-fusion laws, originally designed to disadvantage Democrats, had the unintended effect of solidifying their fate as one of two surviving parties in what became a two-party system. ${ }^{60}$

Purporting to balance the burden of M innesota's anti-fusion rule against the state's interests in enacting its law, the Supreme Court in Timmons acknowledged that the $\mathrm{N}$ ew Party had a right to select the candidate of its choice. ${ }^{61}$ That right, however, did not inexorably lead to the right to select a particular candidate, such as one who was already the nominee of another party. ${ }^{62} \mathrm{~A}$ ccording to the Court, " [t]hat a particular individual may not appear on the ballot as a particular party's candidate does not severely burden that party's association rights." ${ }^{63}$ Because the burden imposed on the New Party's associational rights was not severe, $M$ innesota was not required to provide a compelling justification for its law. ${ }^{64}$ Instead, the state was required only to assert regulatory interests commensurate with the law's impingement. This required no empirical verification of its concerns. ${ }^{65}$

Ignoring the largely partisan genesis of anti-fusion laws, the Court uncritically accepted $M$ innesota's reasons for forbidding fusion politics and even supplied reasons of its own. A lthough the state advanced a number of rationales, such as fear of voter confusion and overcrowded ballots, ${ }^{66}$ both the majority and the dissent gave the most serious and extended consideration to M innesota's interest in preserving the stability of its political system. That interest, according to the six-justice majority, "permits the M innesota L egislature to de-

59. Id. at 304 .

60. See id. But see Pope, supra note 30 , at $484-89$ (arguing that it is equally plausible that fusion bans retarded the decline of third parties since such bans thwarted the tendencies of third parties to lose their identities to their major-party allies).

61. See Timmons, 117 S. Ct. at 1370.

62. See id.

63. Id.

64. See id. at 1372

65. See id.

66. See id. at 1373 . 
cide that political stability is best served through a healthy two-party system." ${ }^{67}$ Thus, the N ew Party's desire to nominate its chosen candidate did not outweigh M innesota's need to "temper the destabilizing effects of party-splintering and excessive factionalism." ${ }^{68}$

In a dissent joined by Justice G insburg and in part by Justice Souter, Justice Stevens chided the majority for even discussing the merits of preserving the two-party system as a justification for $\mathrm{M}$ innesota's fusion ban. ${ }^{69}$ A ccording to J ustice Stevens, M innesota itself had not raised this argument. ${ }^{70}$ J ustice Stevens maintained that, in any event, the risks of factionalism caused by fusion were "speculative at best." ${ }^{71}$ To the contrary:

[T] he fusion candidacy is the best marriage of the virtues of the minor party challenge to entrenched viewpoints and the political stability that the two-party system provides. The fusion candidacy does not threaten to divide the legislature and create significant risks of factionalism, which is the principal risk proponents of the two-party system point to. But it does provide a means by which voters with

\section{Id. at 1374 .}

68. Id.

69. Souter agreed with Stevens that the majority should not have relied on the "preservation of the two-party system" rationale in upholding the statute because the state had not asserted it. Id. at 1381 (Souter, J ., dissenting). He was unwilling, however, to join Stevens in taking the extra step of rejecting the rationale because he could not discount the possibility that it could be a "forceful one." Id. at 1382 (Souter, J ., dissenting).

70. See id. at 1379 (Stevens, J., dissenting).

71. Id. at 1380 (Stevens, J., dissenting). A lthough made in support of another interest"protecting the integrity, fairness, and efficiency of their ballots" - M innesota offered a hypothetical indirectly supporting its concern with excessive factionalism. The state feared that the major parties might become tempted to splinter themselves into several different parties as a means of appealing to various narrow interests. The Court explained the state's concern as follows:

Petitioners contend that a candidate or party could easily exploit fusion as a way of associating his or its name with popular slogans and catchphrases. For example, members of a major party could decide that a powerful way of "sending a message" via the ballot would be for various factions of that party to nominate the major party's candidate as the candidate for the newly-formed "N o N ew Taxes," "Conserve Our Environment," and "Stop Crime Now" parties. In response, an opposing major party would likely instruct its factions to nominate that party's candidate as the "Fiscal R esponsibility," "H ealthy Planet," and "Safe Streets" parties' candidate.

Id. at 1373. J ustice Stevens dismissed this hypothetical as "farfetched." Id. at 1378 (Stevens, J ., dissenting). A $n$ additional and perhaps dispositive difficulty with Minnesota's hypothetical is that it focuses on a kind of factionalism with which the Court has not historically been concerned. No matter how many party labels a candidate runs under, in fusion politics the same candidate is elected. The fact that she may have divided loyalties is not a function of fusion but rather is a common fact of life in a pluralistic democracy. Thus, even a candidate elected solely under the D emocratic banner may have to balance the interests represented by all of the putative parties in the Court's example. 
viewpoints not adequately represented by the platforms of the two major parties can indicate to a particular candidate that-in addition to his support for the major party views-he should be responsive to the views of the minor party whose support for him was demonstrated where political parties demonstrate support-on the ballot. ${ }^{72}$

Thus J ustice Stevens conceptualized the New Party in much the same way as the party, at least in the short term, saw itself: as a complement to two-party stability. The majority's rejection of this view portrayed a one-dimensional understanding of two-party stability, one which may in fact discourage active engagement in the two-party process by political outsiders.

Timmons reflects the Court's continuing inability to articulate intelligible standards for assessing infringements on political parties' associational rights, $^{73}$ and its outcome is difficult to square with precedent. In Tashjian v. R epublican Party of Connecticut, ${ }^{74}$ the Court upheld the state R epublican Party's attack on Connecticut's closedprimary law, which prohibited unaffiliated or independent voters from participating in major-party primaries. ${ }^{75}$ In rejecting Connecticut's assertion that its closed-primary law furthered its interest in fostering a strong two-party system, the Court stated:

The Party's determination of the boundaries of its own association, and of the structure which best allows it to pursue its political goals, is protected by the Constitution. "A nd as is true of all expressions of First A mendment freedoms, the courts may not interfere on the ground that they view a particular expression as unwise or irrational." ${ }^{76}$

L aws that discourage affiliation with any party whatsoever, such as the open primary rule approved in Tashjian, surely threaten states' interest in two-party stability. That is why the Court's favorable treatment of the alliance between Republicans and independents in Tashjian dictates a different result in Timmons. Independent voters pose a far greater threat to two-party political stability than does a

72. Id. at 1380-81 (Stevens, J ., dissenting) (citation omitted).

73. See Smith, supra note 32, at 609-16, 621-28 (criticizing the Court's unwillingness to settle on strict scrutiny as the appropriate standard of review for actions implicating the right to vote).

74. 479 U .S. 208 (1986)

75. See id. at 211.

76. Id. at 224 (quoting D emocratic Party of U nited States v. W isconsin ex rel. L a Follette, 450 U .S. 107, 124 (1981)). 
third party seeking the benefit of fusion, because independent voters, by definition, hinder the maintenance of any party system. ${ }^{77}$

$M$ embers of the New Party had at least portrayed some fidelity to a party system in general by actually belonging to a party, and to the extant party system in particular by seeking to endorse a majorparty candidate. The Court cannot rationally protect the R epublicanindependent arrangement in Tashjian but uphold M innesota's prohibition against a considerably less destabilizing coalition in Timmons. The crucial question ought to be the same as that in Tashjian: has the major party consented to the arrangement at issue? ${ }^{78}$

The road from Tashjian to Timmons is a muddled one. No consistent definition of "two-party stability" emerges from the cases, nor do clear doctrinal rules. 0 ne thing that does emerge, however, is perhaps more than a mere legal coincidence. In Tashjian, a major party-the state R epublican Party-challenged Connecticut's closedprimary rule. By contrast, in Timmons, an outsider group-a third party-mounted a First A mendment challenge seeking access to the two-party process. O ne cannot help but ask whether the Court's receptivity to the mantra of two-party stability is colored by the political position of the party defending against that argument. In Tashjian, an entrenched interest sought to define its associational rights. In Timmons, the N ew Party sought to do the same, but, for reasons

77. The author has previously criticized Tashjian for its short-sightedness regarding Connecticut's interest in two-party stability:

Given the trend toward dealignment [voter disaffiliation with both major parties], the Court should have evaluated more critically the threat that the Party's [open primary] rule posed to Connecticut's stable party government. Because of the Court's failure to undertake a critical examination, Tashjian could have accelerated the dealignment process within Connecticut. Connecticut R epublicans hoped to lure independents to the Party by allowing them to help select the Party's general election candidate. However, in response, the state Democratic Party could adopt the same rule. This would open both parties' primaries to independents and would eliminate the incentive for voters to register with either political party.

Smith, supra note 32, at 612 (footnotes omitted).

78. See Tashjian, 479 U .S. at 215 n.6 (distinguishing Tashjian from cases involving "claims by nonmembers of a party seeking to vote in that party's primary despite the party's opposition"). Some have argued that major parties who decide that fusion is consistent with their long-term interest can always change the anti-fusion law. See, e.g., D aniel H ays Lowenstein, A ssociation Rights of Major Political Parties: A Skeptical Inquiry, 71 TEX. L. REV. 1741, 1790 (1993). The teaching of Tashjian, however, is that absent questions of voter raiding, one major party need not seek the permission of another in order to determine the consensual contours of its membership. See Tashjian, 479 U .S. at $224 \&$ n.13. 
which are difficult to reconcile with Tashjian, its efforts were deemed politically destabilizing to $\mathrm{M}$ innesota. ${ }^{79}$

The Court is conflicted in addressing outsider claims for access to the two-party system, and its confusion prevents it from adhering to the otherwise functional model of politics outlined in D avis. Were the Court's difficulties restricted to claims by minor parties, the damage done to the fabric of the two-party paradigm might be relatively limited. B ut, as explained more fully in Part II, the Court's awkwardness with the New Party's claim is quite similar to its treatment of black voters' efforts to participate in the two-party process in A brams. Indeed, the similarity is more striking than first meets the eye, for the results in both cases are the same: a disparate adverse impact on racial minorities. In focusing on judicial management of partisan factions, D avis assumed away a dominant reality in A merican politics: the racialization of partisan factions. ${ }^{80}$ Timmons emulated this approach, but by treating the New Party as raceless, the Court ignored the disparate impact of its decision on black political participation. This racial transparency ${ }^{81}$ is belied by the New Party's membership. People of color comprise approximately $40 \%$ of the party's membership and national executive committee. ${ }^{82}$ Likewise, $40 \%$ of its candidates are persons of color. ${ }^{83}$ This is no coincidence.

79. While one might intuit that states have less justification to intervene in a party's primary than in the general election, it is difficult to see why the proposed coalition between the $\mathrm{N}$ ew Party and the D emocrats would be more destabilizing than the coalition between the Republicans and independents simply because the former join forces in the general election rather than a primary.

80. See, e.g., D avis v. Bandemer, 478 U .S. 109, 151-52 (1986) (O 'Connor, J., concurring) (comparing racial vote dilution claims to partisan vote dilution claims and concluding that the latter should not be justiciable because "members of the Democratic and R epublican Parties cannot claim that they are a discrete and insular group vulnerable to exclusion from the political process by some dominant group"). But where blacks are an increasingly vital part of the Democratic coalition and whites are correspondingly alienated from that party, see E dward G . Carmines \& Robert Huckfeldt, Party Politics in the Wake of the Voting Rights Act, in Controversies in Minority Voting: The Voting Rights A ct in Perspective 117, 12930 (B ernard Grofman \& Chandler D avidson eds., 1992), partisan gerrymandering may be no different in its effect than racial gerrymandering.

81. See Barbara J. Flagg, Fashioning A Title VII Remedy for Transparently White Subjective D ecisionmaking, 104 Y A LE L.J . 2009, 2012-13 (1995). W hite transparency is "the invisibility of whiteness to whites." Id. at 2012 n.9. The effect of this invisibility is the tacit and unconscious assumption that white norms are neutral despite their disparate effect on racial minorities. See id. at 2012-13.

82. Telephone Interview with A dam Glickman, Communications Director, New Party (Feb. 2, 1998). Ninety percent of the $\mathrm{N}$ ew Party's people of color are A frican-A merican, while some $10 \%$ are L atino. See id.

83. See id. 
The party has made a concerted effort to recruit racial minorities and has used unusual (some would say old-fashioned) means to reach out to these groups. House meetings, churches, meetings of low income unions, and door-to-door organizing are the venues and methods of choice for the N ew Party's recruitment efforts. ${ }^{84}$ W hile the N ew Party aims to become "multi-racial and working-class oriented," ${ }^{85}$ its disproportionate appeal to racial minorities is emblematic of the predisposition that exists among these groups to exit from the traditional two-party system.

A s A brams v. J ohnson limits black options within the traditional two-party structure, fusion politics becomes a desirable substitute for the satellite-type politics in which blacks have traditionally engaged. Fusion politics possesses the complementary features of permitting racial minorities to maintain a separate identity from the major parties-which after Abrams may be necessary-while simultaneously allowing them to form ad hoc electoral coalitions when circumstances warrant. By denying the fusion option to those whom it has alienated from the two-party system, the Court in Timmons undermines twoparty stability, forcing blacks to run against the major parties.

\section{DeferenCE DuE, DEFERENCE DENIED: A BRAMS V. JOHNSON}

J ustice $\mathrm{O}^{\prime} \mathrm{C}$ onnor has cast the deciding vote in three recent Supreme Court decisions that struck down majority-minority congressional districts on the grounds that they were drawn with the excessive use of race. ${ }^{86} Y$ et neither she nor the Court has developed a predictable, coherent conception of when seeking to influence the districting process ceases to be a "critical and traditional" means of

84. See id.

85. Id.

86. See M iller v. J ohnson, 515 U .S. 900 (1995); B ush v. V era, 517 U .S. 952 (1996); Shaw v. H unt, 517 U .S. 899 (1996). In each of the foregoing cases, the five-justice majority consisted of J ustices K ennedy, $O$ 'C onnor, R ehnquist, Scalia and Thomas. J ustice O 'Connor's vote is appropriately characterized as decisive because she is the lone member of this bloc to be on record as believing that the intentional creation of majority-minority districts is not presumptively unconstitutional, see B ush, 517 U .S. at 993 (O 'Connor, J ., concurring) ("[S]o long as they do not subordinate traditional districting criteria to the use of race for its own sake or as a proxy, States may intentionally create majority-minority districts ... without coming under strict scrutiny."); and that compliance with section 2 of the V oting $\mathrm{R}$ ights $\mathrm{A}$ ct, a provision to prevent the dilution of minority voting strength, is a compelling justification for the creation of majority-minority districts. See id. at 976-77. J ustice $O$ 'C onnor's concurrence in B ush and her unpredictable legal analysis in the racial gerrymandering cases have earned her the sobriquet of "swing vote." $M$. Elaine $\mathrm{H}$ ammond, Comment, Toward A M ore Colorblind Society?: Congressional Redistricting A fter Shaw v. H unt and B ush v. Vera, 75 N.C. L. RE V. 2151, 2191 (1997). 
participating in the two-party system ${ }^{87}$ and instead becomes an impermissible use of race. V iewed in terms of J ustice 0 'C onnor's own description of the political process in Davis, the manner in which Georgia's two new majority-black congressional districts were created in A brams is unremarkable. H owever, the Court in A brams, including J ustice $O$ 'C onnor, rejected the $D$ avis Court's conception of redistricting as a normal part of politics, insisting that black legislators' and voters' successful efforts to influence the apportionment process were infected by an impermissible emphasis on race. The disharmony between $D$ avis and $A$ brams suggests a singularly irrational postulate: minority voters are free to engage in the critical and traditional partisan activity of seeking to influence the redistricting process, but success in this endeavor may invalidate its outcome. This improbable legal principle and its inhibiting effect on black participation in the two-party process are explored below.

\section{A. B eyond Black and White}

Suppose members of the Christian Conservative Coalition ${ }^{88}$ in Georgia began flexing their growing political muscle. Coalition members are overwhelmingly white and R epublican, although they tend to outflank R epublicans on the right of certain issues. Principal among these is abortion. The Coalition's platform calls for a constitutional amendment banning all abortions except in cases of rape or incest, or to save the mother's life, as well as for the appointment of only "pro-life" judges to the federal bench. ${ }^{89}$ Furthermore, the platform favors criminalization of the practice of abortion, and endorses jail terms for doctors who perform the procedure. Frustrated that fellow R epublicans rarely go the distance in espousing the Coalition's views on abortion, ${ }^{90}$ the leadership of the Coalition threatens $\mathrm{R}$ epublican members of the G eorgia A ssembly that if they do not create a congressional district favoring the election of R on Davis, a popular

87. See D avis v. B andemer, 478 U .S. 109, 145 (1986) (O 'C onnor, J ., concurring).

88. This is a fictional group, modeled on the Christian Coalition.

89. Cf., e.g., R oni Rabin, Challenging The Religious Right, A im to "O ut" Christian Coalition, NEWSDAY (New Y ork), M ay 21, 1993, at 25 (reporting that the Christian Coalition opposes abortion except in cases of pregnancy due to rape or incest, or when the pregnancy endangers the mother's life).

90. Cf., e.g., L aurie G oodstein, R eligious Right, Frustrated, Trying N ew Tactic on G.O.P., N.Y. TIMES, M ar. 23, 1998, at A 1 (reporting that conservative Christians believe that "the R epublicans they have helped to elect have been too timid and too passive at every crucial juncture"). 
R epublican state legislator who has been a fervent advocate of the Coalition's agenda, the Coalition will actively encourage its members to sit out the next election, which would deprive Republicans of much-needed conservative votes. ${ }^{91}$ The threat poses a serious problem to G eorgia R epublicans: G eorgia is one of the most competitive two-party states in the South, and neither major party can afford to have its support siphoned off. ${ }^{92}$

Believing that on balance R epublicans are better off accommodating the demands of the Christian Conservatives, they agree to draw a congressional seat which would include the entirety of Davis' current legislative district. The Constitution is unlikely to stand in the way of this redistricting. Since major parties can gerrymander to achieve a roughly proportional allocation of seats between themselves, ${ }^{93}$ there is no reason to believe that they cannot gerrymander to maintain an electoral coalition that is critical to the party's success at the polls. ${ }^{94} \mathrm{M}$ oreover, $\mathrm{D}$ avis is for all practical purposes an incumbent to a substantial part of the district in which he will be running, and the Supreme Court has sanctioned gerrymandering in aid of incumbents. ${ }^{95}$ Thus, Christian Conservatives could lobby the legislature for favored treatment in the districting process without occasioning constitutional scrutiny.

91. Cf. Katharine Q. Seelye, Christian Coalition Criticism Irks G .O .P. L eader, N.Y. TIM ES, A pr. 3, 1998, at A 24 (reporting that because the Christian Coalition believes that the R epublican Party "has been too accommodating to those who support abortion rights," the group has threatened to form a third political party); cf. Goodstein, supra note 90 (noting that the Christian right is currently focused on identifying and supporting conservative politicians in local races).

92. See Michael Barone \& Grant Ujifusa, Almanac of American Politics 327 (1994).

93. See, e.g., G affney v. Cummings, 412 U .S. 735, 754 (1973) ("[W e do not have] a constitutional warrant to invalidate a state plan ... because it undertakes, not to minimize or eliminate the political strength of any group or party, but to recognize it and, through districting, provide a rough sort of proportional representation in the legislative halls of the state.").

94. The R epublicans' deal with $\mathrm{R}$ on $\mathrm{D}$ avis is a necessary precondition to achieving a partisan gerrymander and is, in effect, a partisan gerrymander in favor of the Republican Party. While it may be true that the motive for the partisan gerrymander is the threat of $D$ avis' supporters sitting out the election, the end result of the negotiation between Christian Conservative voters and R epublicans in the state legislature is a partisan gerrymander consistent with G affney v. Cummings.

95. See, e.g., White v. Weiser, 412 U .S. 783, 797 (1973) ("'The fact that district boundaries may have been drawn in a way that minimizes the number of contests between present incumbents does not in and of itself establish invidiousness." (quoting B urns v. R ichardson, 384 U.S. 73, 89 n.16 (1966))). Cf. K archer v. D aggett, 462 U .S. 725, 740 (1983) (“A ny number of consistently applied legislative policies might justify some variance [in the population of congressional districts], including, for instance, avoiding contests between incumbents."). 
Now imagine a third party in Georgia called the New Black and Tan Party. ${ }^{96}$ Its membership is composed almost exclusively of A frican-A mericans. The party was created because its constituents' beliefs, life experiences, and political philosophies differ markedly from those of the average white Georgian. For instance, a significant number of N ew Black and Tan Party members believe that they are not treated equally in their communities. ${ }^{97}$ In addition, a majority of the party's members believe that they are not treated equally by the police. ${ }^{98}$ The members' perceptions are not without foundation. Research data show that a majority of whites view blacks as less intelligent, less hardworking, and less patriotic. ${ }^{99}$ It would be surprising if these opinions were not reflected in whites' interactions with blacks. Likewise, it is unsurprising that $\mathrm{New}$ Black and Tan members' personal experiences and perceptions tend to translate themselves into policy preferences. A majority of members, for instance, favor increasing government affirmative action programs, while only approximately $22 \%$ of white $\mathrm{G}$ eorgians support such a step. ${ }^{100}$ These differences are not isolated but instead reflect a racial schism in policy preferences between blacks and whites. ${ }^{101}$ Thus, a considerable gulf

96. This is a fictional party based on the Black and Tan R epublicans. See infra notes 225226 and accompanying text.

97. Cf. Gallup Org., The Gallup Poll Social Audit on Black/White Relations IN THE UNITED STATES 6 (J une 10, 1997). The poll reported that only $49 \%$ of black respondents said they were treated equally, while $76 \%$ of white respondents believed blacks were treated equally. Forty-five percent of blacks said they either were not treated as well as whites or were treated badly. See id. These findings reflect a nationwide sample group. For convenience, the author assumes they reflect G eorgians' opinions reasonably accurately.

98. Cf. id. at 9 (reporting that $60 \%$ of black respondents believed that they were treated less fairly by police, while only $30 \%$ of whites believed blacks were treated less fairly).

99. See D avid Benjamin O ppenheimer, Understanding A ffirmative Action, 23 HA STINGS CONST. L.Q. 921, 950-52 (1996) (discussing the findings of a $1990 \mathrm{~N}$ ational O pinion R esearch Center study).

100. See GA LLUP ORG ., supra note 97 , at 14

101. See Michael C. Dawson, Behind the Mule: Race and Class in AfricanA MERICAN POLITICS 182 (1994):

[E ]ight years after the 'conservative revolution' heralded by the election of R onald Reagan, extraordinary political divisions persisted between blacks and whites.... [T wenty- and thirty-] percentage point gaps between blacks and whites on some issues are not uncommon, and often the two races end up on opposite sides of critical policy questions. These enormous gaps serve to overwhelm what would normally be considered significant variation in A frican-A merican public opinion, thus helping to explain the seeming homogeneity of A frican-A merican political behavior.

Illustrative of this philosophical and political divergence are the views of blacks and whites on government spending: $63 \%$ of blacks support increased spending on government services, while only $33 \%$ of whites favor such a step. See id. at 183. 
separates members of the New B lack and Tan Party from members of the two major parties, most of whom are white.

Suspend disbelief for a moment longer and imagine that most of Georgia's $28 \%$ black population belong to the New Black and Tan Party. ${ }^{102}$ D emocrats, training their sights on the most powerful statewide offices, cut a deal with the N ew Black and Tan leadership. Specifically, the D emocrats say, "in the next decennial reapportionment, we'll allot your party a proportionate share of the congressional seats if you promise to support our gubernatorial and U nited States Senate candidates." U nless any self-interested political activity by a majority-black party is impermissibly race-based, while the same activity by a predominantly white group is not, no Supreme Court precedent prohibits the above arrangement. Indeed, according to the Court, "judicial interest should be at its lowest ebb when a State purports fairly to allocate political power to the parties in accordance with their voting strength and, within quite tolerable limits, succeeds in doing so." ${ }^{103} \mathrm{~N}$ or, under the Court's political gerrymandering jurisprudence, should it matter that New Black and Tan Party members are somewhat geographically dispersed, thus requiring the creation of oddly shaped congressional districts in order to give its members majority status in approximately a fourth of the state's congressional districts. A gain, in the Court's own words, "compactness or attractiveness has never been held to constitute an independent federal constitutional requirement for state legislative districts," ${ }^{104}$ and, as for congressional districts, "[d]istricts not drawn for impermissible reasons or according to impermissible criteria may take any shape, even a bizarre one." 105

Under the hypothetical deal struck above, the New Black and Tan Party would be entitled to three of Georgia's eleven congressional seats, the same number of black-majority districts that were in

102. See U.S. Dep't of Commerce, Statistical a bStract of the United States 34 (117th ed. 1997) [hereinafter STA TISTICA L A BSTRACT] (reporting G eorgia's total population in 1997 as 7,055,000, with a black population of $1,966,000$ ).

103. G affney v. Cummings, 412 U .S. 735,754 (1973).

104. Id. at 752 n.18. But see Miller v. Johnson, 515 U.S. 900, 916 (1995) (holding that "circumstantial evidence of a district's shape and demographics" can help to "prove that the legislature subordinated traditional race-neutral districting principles, including ... compactness ... to racial considerations").

105. Bush v. V era, 517 U.S. 952, 999 (1996) (Kennedy, J., concurring). But see Shaw v. Reno, 509 U .S. 630, 642 (1993) (stating that "redistricting legislation that is so extremely irregular on its face that it rationally can be viewed only as an effort to segregate the races for purposes of voting" can be challenged as violating the Equal Protection Clause). 
fact created by the state legislature in $1992 .{ }^{106}$ In A brams v. J ohnson, however, the Court concluded that the creation of more than one black congressional district in Georgia would offend the Constitution's guarantee of equal protection by impermissibly allowing race to predominate in the redistricting process. ${ }^{107}$ What is the difference between the black voters in the above hypothetical and actual black voters in G eorgia? The latter are D emocrats, not members of a third political party. Thus, Democrats cannot do for their own members what they could theoretically do for a third party. Nor can they do for blacks what R epublicans can do for the Christian Conservative Coalition, even though blacks are as central to the Democrats' electoral success as Christian (and largely white) conservatives are to the R epublicans'. ${ }^{108}$

\section{B. Seeing O nly Black and White}

In the face of the Supreme Court's avowed commitment to a stable two-party system, a rule of law that makes it possible for a third party to achieve what an interest group within one of the major parties cannot is irrational on its face. $Y$ et the Court's attempt to isolate notions of two-party stability from its recent racial gerrymandering decisions has wrought such an outcome. The Court's current campaign to cleanse the redistricting process of the perceived excessive use of race began with Shaw v. Reno. ${ }^{109}$ A lluding to, but never demonstrating, the dangers of stereotyping created by placing racial minorities into voting districts in which they are a majority, the Court in Shaw demanded compelling justification where race was the overriding districting criterion. ${ }^{110}$ Strict scrutiny was necessary, according to the Court, because reapportionment based on race "reinforces the perception that members of the same racial group-regardless of their age, education, economic status, or the community in which

\footnotetext{
106. See A brams v. J ohnson, 117 S. Ct. 1925, 1930-31 (1997).

107. See id. at 1934-35.

108. See Carmines \& Huckfeldt, supra note 80 , at 131 (documenting increasing share of Democratic presidential votes cast by blacks); David Grann, Close Races, NEW REPUBLIC, Mar. 9, 1998, at 11, 14 (regarding blacks as the Democratic Party's "most devoted constituency"); G oodstein, supra note 90, at A 1 ("The R epublican Party is built on an uneasy alliance of social conservatives, a constituency that includes the religious right, and economic conservatives, committed to a smaller-government, lower-tax agenda.").

109. 509 U .S. 630 (1993).

110. See id. at 647 .
} 
they live-think alike, share the same political interests, and will prefer the same candidates at the polls." 111

The Court subsequently applied its Shaw holding to a Georgian majority-black congressional district in Miller v. Johnson. ${ }^{112} \mathrm{M}$ iller heralded two important themes that would recur in the Court's reverse-racial gerrymandering decisions. First, the presence of race was an inevitable feature of the redistricting process. ${ }^{113}$ Second, M iller established that irregular shape was not a prerequisite to challenging a district as an unconstitutional gerrymander. ${ }^{114}$ Instead, courts must examine the totality of the circumstances to determine whether a racial purpose predominated in the creation of a given district. ${ }^{115} \mathrm{~W}$ hile commentators have opined that Miller fails to delineate clearly between permissible and impermissible race-conscious districting, ${ }^{116}$ few have noted the constraints Miller would impose on the lobbying of those who promote districting beneficial to racial minorities. Unlike in Shaw, where the odd shapes of the black congressional districts provided the principal evidence of the predominance of race, ${ }^{117}$ the Court in M iller subjected G eorgia's D istrict E leven to strict scrutiny in large part because the legislative process had allegedly overemphasized racial concerns. ${ }^{118}$ Indeed, the Court in Miller conceded that "by comparison with other districts the geometric shape of the Eleventh District may not seem bizarre on its face." ${ }^{119}$ Considering "additional evidence" gleaned from the give-and-take of the legislative process, however, the Court was able to detect what it believed was the predominance of race in Georgia's redistricting plan. ${ }^{120}$ The Court ultimately struck down D istrict E leven for failing to satisfy the

111. Id.

112. 515 U .S. 900 (1995).

113. See id. at 916 ("Redistricting legislatures will ... almost always be aware of racial demographics....").

114. See id. at 912-13.

115. See id.

116. See, e.g., J ohn H art Ely, G errymanders: The Good, the Bad, and the U gly, 50 STA N. L. REV . 607, 611 (1998) (describing Miller's dominant purpose test as "vague and manipulable" and even "incoherent"); Samuel Issacharoff, The Constitutional Contours of Race and Politics, 1995 SU P. CT. RE V. 45, 55-56 (criticizing the M iller test).

117. See Shaw v. Reno, 509 U .S. 630, 642 (1993). The white plaintiffs in Shaw objected to North Carolina's congressional districting plan because it was "so extremely irregular on its face that it rationally can be viewed only as an effort to segregate the races for purposes of voting." Id.

118. See M iller, 515 U .S. at $917-20$.

119. Id. at 917.

120. See id. 
most exacting constitutional scrutiny. ${ }^{121}$ It is helpful to review M iller's attention to legislative process as a predicate for understanding the import of A brams v. J ohnson.

A s a jurisdiction covered by the V oting Rights A ct, G eorgia, like most southern states, must seek federal approval of its decennial congressional redistricting prior to implementing any changes. ${ }^{122}$ It may seek such "preclearance" from the U nited States J ustice Department, or, alternately, it may seek a declaratory judgment from the U nited States District Court for the D istrict of Columbia that its redistricting "does not have the purpose and will not have the effect of denying or abridging the right to vote on account of race or color [or language]." ${ }^{123}$ The Justice D epartment's determination is never binding on a covered jurisdiction; at all times the state remains free to seek a declaratory judgment from the federal district court. ${ }^{124}$

O pting for the administrative route, G eorgia sought J ustice D epartment preclearance of its decennial congressional redistricting in 1991. The state's original plan, fashioned by its General A ssembly, contained two majority-black districts, an increase of one from the preceding decade. ${ }^{125}$ The J ustice Department, however, refused to preclear this plan, citing the possibility of placing more minorities in

121. See id. at $926-28$

122. See id. at 905. A state or locality becomes a covered jurisdiction under section 5 of the $V$ oting R ights A ct if it (1) maintained, as of a statutorily prescribed date, a "test or device" as a prerequisite to voting and (2) the Director of the Census determines that less than $50 \%$ of the jurisdiction's voting age population were registered to vote or participated in the presidential election of the indicated year. See 42 U .S.C. $§ 1973$ b(b) (1994). The terms "test or device" refer to literacy and character tests. 42 U .S.C $\S 1973 b$ (c). The combination of the use of a test or device and low voter turnout correlates with covered jurisdictions' histories of discrimination against blacks at the polls:

Tests and devices are relevant to voting discrimination because of their long history as a tool for perpetrating the evil; a low voting rate is pertinent for the obvious reason that widespread disenfranchisement must inevitably affect the number of actual voters. A ccordingly, the coverage formula is rational in both practice and theory.

South Carolina v. K atzenbach, 383 U .S. 301, 330 (1966). This coverage formula brought G eorgia under the preclearance requirements of section 5 as of $A$ ugust 7,1965 . See id. at 318.

123. See 42 U .S.C. §§ 1973b(f)(2), 1973c (1994).

124. See id. § 1973c. See also SAMuel ISSA Charoff ET AL., The LaW OF Democracy: Legal Structure Of The Political Process 329 (1998):

A Ithough the A ttorney $G$ eneral's preclearance determination is not subject to judicial review, his objection may be overridden as a practical matter, since a jurisdiction may seek a declaratory judgment from the D istrict of Columbia D istrict Court without regard to whether an objection was interposed in the administrative process. That declaratory judgment is an entirely separate proceeding in which the administrative objection plays no role.

125. See Miller, 515 U .S. at 906. 
majority-black districts. ${ }^{126}$ When in a subsequent submission the state adhered to its two-district plan while increasing each district's black populations, the J ustice D epartment again refused preclearance, this time citing the possibility of creating a third majority-black district. ${ }^{127}$ The M iller Court suspected that the J ustice D epartment's views had been influenced by a draft plan advocated by the A merican Civil Liberties U nion, dubbed the "max-black" plan. ${ }^{128} \mathrm{U}$ nder this proposal, various black populations in the majority-black Eleventh D istrict would be transferred to the Second D istrict, converting it into a third majority-black district. Tracking this plan, the G eorgia legislature proposed a redistricting plan containing three majority-black congressional districts. ${ }^{129}$ The plan was precleared by the J ustice D epartment and resulted in the election of three black congressmen. ${ }^{130}$ Relying on Shaw v. Reno, voters in the Eleventh District sued, claiming that the district was drawn on predominantly racial grounds. ${ }^{131}$

In determining that race had overwhelmed the redistricting process, the Miller Court relied not merely on the odd shape of District Eleven, ${ }^{132}$ as it appeared to do in Shaw, ${ }^{133}$ but also on the advocacy of groups whose statutory (the J ustice Department), organizational (the ACLU) and political (black legislators) roles were to pursue results beneficial to minority voters. ${ }^{134} Y$ et this kind of participation in the districting process on the part of blacks-even when

\footnotetext{
126. See id. at $906-07$.

127. See id. at 907.

128. See id. at 907-09. The J ustice D epartment denied this, maintaining instead that it was seeking to ensure that G eorgia did not have a discriminatory purpose when it refused to create three black districts in its first two preclearance submissions. See id. at 924. The weight of history supported the J ustice D epartment's contention. In the 1981 round of redistricting, white Democratic elected officials had hostilely opposed the creation of a majority-black congressional district. The Chairman of the G eorgia H ouse Permanent Standing Committee on Legislative and Congressional Reapportionment, Joe Mack Wilson, had referred to blacks as "niggers" and stated that he opposed the creation of a black district because he opposed "nigger legislation." B usbee v. Smith, 549 F. Supp. 494, 500 (D.D.C. 1982), aff'd, 459 U .S. 1166 (1983). Likewise, the Speaker of the G eorgia H ouse, Thomas M urphy, expressed opposition to the creation of "a black district where a black would certainly be elected." Id. at 509-10. Given this abysmal recent history, the J ustice $D$ epartment was only wise to inquire whether racism led the $\mathrm{G}$ eorgia A ssembly to restrict the number of black congressional districts to two.
}

129. See M iller, 515 U .S. at 907-08

130. See id. at 909.

131. See id.

132. See id. at 917.

133. See Shaw v. R eno, 509 U .S. 630, 642 (1993).

134. See M iller, 515 U.S. at 907-08. 
aided by the federal government or other organizations-is precisely what J ustice 0 'C onnor recognized in $\mathrm{D}$ avis as core participation in the two-party system ${ }^{135}$ Since it is not illegal for a federal agency to take sides in a policy dispute falling within its jurisdiction, and since the ACLU certainly has a First A mendment right to petition the government, the Court was misguided in resting the brunt of its analysis on the roles of these entities in aiding black $\mathrm{G}$ eorgians during the redistricting process.

The Court in Miller allied itself with the lower court's derisive conclusion that "'[the J ustice D epartment] would accept nothing less than abject surrender to its [black] maximization agenda.'" ${ }^{136}$ Furthermore, although the very reason Georgia's redistricting was subject to preclearance under section 5 was the state's past resistance to the black franchise, ${ }^{137}$ the Court relied on the potentially selfinterested statements of white Georgia officials who opposed the creation of a third black district to bolster its conclusion that the J ustice Department had forced Georgia to over-emphasize race. ${ }^{138}$ Oddly, the Court's focus on the legislative and preclearance processes-rather than the geographical shape of the new black districtthreatened to silence advocates of minority interests while potentially empowering voices which had historically been resistant to those interests. M oreover, in finding Georgia's District Eleven unconstitutional, the Court made blacks the victims of their own success, even though it is probable that if these voters had been any less vigorous in pursuing their interests, they would have been entirely neglected. ${ }^{139}$ Thus, M iller created a black periphery in the two-party system. A fter Miller, a major party can accommodate its black constituency only at its own risk, for courts may now use blacks' demands for representa-

135. See D avis v. B andemer, 478 U .S. 109, 145 (1985) (O 'Connor, J ., concurring).

136. M iller, 515 U .S. at 917 (quoting J ohnson v. M iller (J ohnson I), 864 F. Supp. 1354, 1366 n.11 (S.D. Ga. 1994)).

137. See South Carolina v. Katzenbach, 383 U.S. 301, 333-34 (1966) (noting that G eorgia had used literacy tests to disenfranchise blacks, and noting that the use of such tests as well as depressed voter turnout were the triggering elements for coverage under the Voting Rights A ct). See also L aughlin M cD onald et al., Georgia, in QuiEt Revolution In The South: The IMPACT OF THE VOTING RIGHTS A CT, 1965-1990, at 67 (Chandler Davidson et al. eds., 1994) (detailing "two centuries of deliberate and systematic discrimination [in elections] by the state against its minority population").

138. See, e.g., M iller, 515 U .S. at 919 (noting the G eorgia A ttorney G eneral's objection to the creation of a third black district).

139. For inferential support of this view, one need only examine the behavior of white Georgia legislators during the 1981 redistricting when the state resisted the creation of even one black congressional district. See supra note 128 . 
tion, and any reinforcement they receive from the Justice Department or other entities, as evidence that a state has gone too far in acceding to such demands. This new regime threatens the two-party stability principles enunciated by Justice $\mathrm{O}^{\prime}$ Connor in $\mathrm{D}$ avis $\mathrm{s}^{140}$ and espoused by a majority of the Court in Timmons. ${ }^{141}$

Since the Court found the plan calling for three black districts to be unconstitutionally infected by race, ${ }^{142}$ it fell to the G eorgia legislature to cure this infirmity. When the Georgia legislature failed at its efforts to reconfigure its congressional map pursuant to Miller, the district court had two options: it could either revive earlier state proposals containing two majority-black congressional districts, or it could fashion its own remedy. ${ }^{143}$ The district court recognized that it was constrained in its ability to fashion its own remedy by U pham $v$. Seamon, ${ }^{144}$ a case which held that a court-imposed redistricting plan must depart from the legislature's policies only to the extent necessary to cure the constitutional violation at issue. ${ }^{145}$ The benchmark for determining the political preferences of the G eorgia legislature lay at the heart of the controversy in A brams.

The district court concluded that it was not bound by the earlier districting plans containing two black districts, ${ }^{146}$ even though both of those plans were passed by majorities in the Georgia legislature. ${ }^{147}$ A ccording to the court, it was not required to use either of these plans as a point of departure because both were the products of "unconstitutional DOJ interference" rather than the will of the G eorgia legislature. ${ }^{148}$ The court did not explain how the J ustice D epartment's role in the redistricting process could render the 1991 plans coerced when Georgia remained free to seek a declaratory

\footnotetext{
140. See supra note 43 and accompanying text.

141. See supra notes 66-68 and accompanying text. (S.D. Ga. 1995).

143. See J ohnson IV, 922 F. Supp. at 1560.

144. 456 U .S. 37 (1982).

145. See id. at 42.

146. See J ohnson IV, $922 \mathrm{~F}$. Supp. at 1560.

147. See A brams v. J ohnson, 117 S. Ct. 1925, 1927 (1997).

148. Johnson IV, 922 F. Supp. at 1560.
}

142. The Court in Miller only upheld the district court's invalidation of D istrict E leven. See M iller, 515 U .S. at 909. A fter the case was remanded to the district court to fashion an appropriate remedy, that court granted plaintiffs' motion for leave to add residents of G eorgia's Second District to challenge the constitutionality of that district. See J ohnson v. M iller (J ohnson IV), 922 F. Supp. 1556, 1559 (S.D. Ga. 1995). The district court concluded that District Two had been created in much the same way as D istrict E leven, and that D istrict T wo was therefore also unconstitutionally drawn. See Johnson v. Miller (J ohnson III), 922 F. Supp. 1552, 1553 
judgment from a federal district court at every stage of the preclearance process. Instead, the court repeated its earlier misgivings about the J ustice Department's role and proceeded to devise its own plan which reduced the number of majority-black congressional districts from three to one ${ }^{149}-$ a number representing only $9 \%$ of the congressional districts in $\mathrm{G}$ eorgia, compared to its $28 \%$ black population.

The court recognized, however, that its own plan needed to comply with the Voting Rights A ct of 1965 . U nder section 2 of the A ct, ${ }^{150}$ black voters may make out a claim of racial vote dilution where they demonstrate that: (1) they are sufficiently numerous and compact to constitute a majority in a single member district; (2) they are politically cohesive; and (3) white voters vote as a bloc so as to consistently defeat the minority-preferred candidate. ${ }^{151}$ While the court acknowledged the constraints of the A ct, it found that section 2 did not require it to create a second black district because there was insufficient evidence of geographic compactness and racial bloc voting. ${ }^{152}$

Defendant-intervenors who sought the creation of a second black district appealed the lower court's ruling. E mploying the same focus on the legislative process adopted in M iller, the Supreme Court in A brams upheld the district court's conclusion that it could not defer to the state's earlier two-district plans because they, too, reflected an overuse of race. ${ }^{153}$ It first cited testimony from G eorgia's Director of R eapportionment Services that the second black district, like the third, had been designed as a concession to the J ustice D epartment's max-black demands. ${ }^{154}$ This testimony, however, amounted to little more than an unsurprising admission that Georgia, long resistant to the black franchise, may have required pressure to increase the number of its black congressional districts from the tokenage of one to a more representative and equitable number. For that matter, the testimony was merely proof of the political adage to which all interest groups must adhere: if you want something, insist on it. The Court, however, elected to measure black participation in the two-party process by an inhibiting set of standards.

149. See id. at 1561

150. V oting Rights A ct of 1965, Pub. L. No. 89-110, § 2, 79 Stat. 437 (codified as amended at 42 U .S.C. $\S 1973$ (1994)).

151. See Thornburg v. G ingles, 478 U .S. 30, 50-51 (1986) (construing section 2).

152. See ohnson IV, $922 \mathrm{~F}$. Supp. at 1566.

153. See A brams, 117 S. Ct. at 1934.

154. See id. at 1934. 
The Court also found Georgia's two-district plan unconstitutional because the black caucus of the Georgia legislature and the legislature's D emocratic leadership had arrived at an understanding in 1991 that there would be at least two black congressional districts. This understanding, according to the Court, was reached "in the shadow of the Justice Department's max-black goal." ${ }^{155}$ But there would be little point in having black legislators in the Georgia A ssembly and Senate if they did not attempt to advance the unique interests of their constituents, whether in the redistricting process or in the passage of substantive legislation. $\mathrm{H}$ ad these legislators remained silent or been less vigorous in pursuing an increase in black congressional representation, their constituents undoubtedly would have viewed such passivity as derelict. Moreover, it cannot violate the Constitution for black legislators to cut deals on behalf of their constituencies unless the Constitution also prohibits white legislators from doing the same. Given the considerable degree to which racial prejudice influences white attitudes on the broad range of policy issues that the redistricting process is intended to reflect, the creation of white districts is no less a racial act than the creation of black ones. ${ }^{156}$

155. Id.

156. It is only by treating the creation of white districts as racially transparent, or neutral, see supra note 81 , that one can portray the dealmaking of the black legislators as exceptional. But given the prevalence of black stereotypes among whites, see supra note 99 and accompanying text, and the distinctly racial genesis of R epublican conservatism, see infra note 180 , the assumption of racial neutrality is simply untenable. The policy choices and political preferences of whites-choices and preferences that the redistricting process attempts to take into account-are influenced by racial prejudice. R esearchers have documented that at least $42 \%$ of white southerners object to living next door to a black family. See James $\mathrm{H}$. Kuklinski et al., Racial Prejudice and A ttitudes T oward A ffirmative A ction, 41 A M. J. PoL. SCI. 402, 407 (1997). While this astonishing level of bigotry cannot alone explain the pervasive white southern opposition to affirmative action, see id. at 408 , researchers do not dispute some causal relationship between white prejudice and opposition to affirmative action. See id. at 408, 413, 414 (explaining racial prejudice as one source, but not the sole source, of opposition to affirmative action). See also Donald R. Kinder \& Tali Mendelberg, Cracks in A merican A partheid: The Political I mpact of Prejudice among D esegregated Whites, 57 J. PoL. 402, 403 (1995) ("[M ]any white A mericans continue to harbor emotionally charged derogatory beliefs about blacks and ... such beliefs figure prominently in whites' opposition to policies designed to narrow racial inequalities.").

The effects of stereotypes and prejudice are not limited to overtly racial issues like affirmative action. White attitudes toward criminal justice policies are substantially influenced by race. See J on H urwitz \& M ark Peffley, Public Perceptions of Race and Crime: The Role of Racial Stereotypes, 41 A M. J. PoL. SCI. 375, 393 (1997) (noting "a substantial and recurrent overlap between negative A frican-A merican stereotypes and more punitive views of crime policy among.... white respondents over a variety of survey experiments"). Similarly, whites' views 
Even if the J ustice D epartment pressured the Georgia legislature to create a second black district, its arm-twisting was irrelevant in assessing that district's constitutionality. To begin with, there was ample evidence that this result would have been reached whether or not the J ustice Department had intervened. There were thirty-five blacks in G eorgia's 236 member legislature, nine of them committee chairmen. ${ }^{157}$ Black voters had proven themselves extremely loyal D emocratic voters in Georgia. ${ }^{158}$ Consequently, maintenance of the one-black-congressman status quo was politically untenable. The fact that this constituency was a racial minority asserting its own distinct interests does not delegitimize its "critical and traditional" input into the party process. ${ }^{159} \mathrm{~A}$ gainst this backdrop, it was simply conjecture for the Court to conclude that J ustice D epartment pressure to implement a max-black plan, rather than Democrats' need to accommodate a constituency as powerful as the black community was in 1991, accounted for the passage of the two-district plan. Even if it did, however, J ustice B reyer was surely correct to ask:

How can a court say that a legislative A ct is legitimate-that it reflects legislative preferences or policies when those who reason or cajole (or threaten suit) are farmers, businessmen, or consumer groups, but that the same legislative A ct becomes illegitimate-that it does not reflect 'true' legislative policy or preference-simply because those who seek to persuade (or threaten suit) represent the Justice Department. [sic] One cannot say that the Department's power is any less legitimate than that exercised by the many other groups that seek to influence legislative decisions; and its employees' sworn duty to uphold the law would seem more suitably character-

regarding welfare policy are "heavily colored by their racial stereotypes." M ark Peffley et al., Racial Stereotypes and Whites' Political Views of B lacks in the Context of Welfare and Crime, 41 A M. J. POL. SCI. 30, 44 (1997). R acial isolation exacerbates the degree to which prejudice informs whites' policy preferences, for "[r]acial isolation may leave many white A mericans susceptible to propaganda, rumor, and their own stereotypes...." K inder \& M endelberg, supra, at 420. This finding is particularly significant given that nearly half of white A mericans report no blacks living in their neighborhood, and "less than $10 \%$... report working with substantial numbers of blacks." Id. at 417.

In sum, to the extent that white districts reflect the shared interests of whites, these districts are by their very nature racial. Y et, the Court dare not apply a "predominance" test to white districts to determine whether they are drawn with a racial purpose in mind.

157. See Steve H arvey, State's B lack Caucus at crossroads as it marks 25 years, A TLA NTA J. $\&$ CONST., O ct. 10, 1992, at B 5.

158. See, e.g., Leonard Pallats, Georgia Voters Split Evenly on Parties, CHATTANoogA FREE PRESS, Dec. 1, 1996, at C1 (noting strong Democratic voting habits among Georgia's blacks).

159. See D avis v. B andemer, 478 U .S. 109, 144-45 (1986) (O 'Connor, J ., concurring). 
ized as a reason for paying greater attention to its views rather than as a reason for heeding them less. ${ }^{160}$

\section{J ustice Breyer's dissent rightly skewers the majority for treating the creation of Georgia's new black congressional districts as a case of overzealous administrative enforcement. ${ }^{161}$ The majority's depic-}

160. A brams, 117 S. Ct. at 1945 (B reyer, J ., dissenting).

161. O ne commentator has agreed with this portrayal of the J ustice D epartment's activity in the racial gerrymandering cases, concluding states were "the victims" of DOJ intervention. Daniel $H$ ays L owenstein, $Y$ ou D on't $H$ ave to Be $L$ iberal to $H$ ate the Racial Gerrymandering Cases, 50 StA N. L. Rev. 779, 780 (1998). Professor Lowenstein argues that racial gerrymandering cases such as A brams punish states for capitulating to federal pressure to create majority-minority districts by divesting those states of control over their redistricting once such districts are declared unconstitutional because race predominated in their creation. See id. at 783, 816. He maintains that a "genuinely conservative Court," rather than punishing covered jurisdictions by derogating from their constitutional prerogative to perform their own redistricting, would either lessen or eliminate the federal mandate for majority-minority districts. Id. at 826 . L eft to the states, majority-minority districts will continue to be created, but "state legislatures, acting on their own, do not carry race-based districting to excess." Id. at 828 . Thus, instead of privileging racial minorities by guaranteeing them a floor below which the number of majorityminority districts may not fall, blacks and $\mathrm{H}$ ispanics may "engage freely in the political process of competition and negotiation." Id. at 830.

There is, of course, a certain mischief to labeling the State of G eorgia a "victim" in the context of the federal mandates imposed on it under the V oting R ights A ct. G eorgia's virulent history of racial discrimination against blacks at the polls, a history that includes the use of literacy tests, subjected it to the preclearance requirements of the A ct. See supra note 122. $M$ oreover, the state need not continue to subject itself to preclearance at all, as the Voting Rights A ct allows a jurisdiction to "bail out" upon a showing to the U nited States District Court for the District of Columbia that, inter alia, "during the ten years preceding the filing of the action" Georgia has not used a test or device "for the purpose or with the effect of denying or abridging the right to vote on account of race or color." 42 U .S.C. § 1973b(a)(1)(A ) (1994). G eorgia, however, remains subject to preclearance, a fact which is indicative of its continuing discrimination against minorities. See M iller v. J ohnson, 515 U .S. 900, 905 (1995).

Perhaps the greatest difficulty with L owenstein's depiction of the relationship between the DOJ and the states is its ahistoricism. Like the Court in Abrams, Lowenstein implicitly denigrates the historical alliances of minorities and the federal government in fighting for civil rights. See Lowenstein, supra, at 812-16 (portraying the states as victims and pointing to DOJ inflexibility as a cause of states' difficulties in redistricting). For more than a century, blacks have been compelled to seek the aid of the federal government in advancing their civil rights. The N ational E qual R ights L eague lobbied Congress after the Civil W ar for passage of legislation conferring on blacks the right to vote. See AuguSt MEIER, NEgRO THOUght IN A MERICA , 1880-1915, at 6 (1963). A nd the same J ustice D epartment that the Court so vigorously criticized in A brams intervened on numerous occasions during the 1960s to ensure the First A mendment rights and safety of black civil rights activists in the South. See HANES Walton, When the Marching Stopped: The Politics of Civil Rights Regulatory A GENCIES 181 (1988) (discussing the three eras of civil rights enforcement by federal regulatory agencies and characterizing the 1960s as a period when "the federal government [was] forced to step away from the sidelines and take sides with the [civil rights] movement and against those who used violence and fraud to deny individuals their basic human rights"). While the cause for which the federal government's aid is enlisted should not insulate any ac- 
tion makes even less sense when one considers that Georgia at all times remained free to seek a determination from a three-judge court regarding whether its 1991 redistricting plan complied with the V oting R ights A ct. ${ }^{162}$ Thus, if the state ever intended to submit and preclear a plan with fewer than two majority-black districts, it could have done so, and the J ustice D epartment could not have stood in the way. It failed to exercise this option, presumably because it had always intended to have at least two black districts. The Court's exaggerated view of the J ustice D epartment's power, however, effectively reduced the autonomy of G eorgia's legislature and rendered the Democratic Party of G eorgia unaccountable to black voters in the redistricting process.

The Court's baffling focus on the role of the D OJ obfuscated the more fundamental question of the legitimacy of black group identity politics that lay at the heart of A brams. The Court's behavior was especially curious because $A$ brams presented the Court with an opportunity to affirm and elucidate its decision in Romer V. E vans, ${ }^{163}$ the case which invalidated Colorado's proscription against laws prohibiting discrimination against homosexuals. ${ }^{164}$ The Court found that by prohibiting its legislature or localities from enacting laws to protect homosexuals, Colorado had rendered it "more difficult for one group of citizens than for all others to seek aid from the government... a denial of equal protection of the laws in the most literal sense." ${ }^{165} \mathrm{~B}$ ut if lesbians and gays are entitled to petition their governments for salutary legislation, does not the Equal Protection Clause allow blacks to do the same, without fear that their efforts will later be used against them to show an overemphasis on race? In the context of the two-party process and one of its core activities-redistrictingA brams renders it more difficult for blacks to seek beneficial legislation from their governments for no other reason than their choice to identify their political interests through the prism of their race. A fter Romer and A brams, group identity politics is a right of homosexuals which cannot be exercised by the very group for whom the Fourteenth A mendment was especially enacted.

\footnotetext{
tivity from constitutional scrutiny, neither should the fact of government intervention give rise to constitutional suspicion.

162. 42 U.S.C. § 1973b(a)(5) (1994).

163. 517 U.S. 620 (1996)

164. See id. at 623-24.

165. Id. at 633 .
} 
The Supreme Court's scrutiny of the lobbying of black legislators and their allies wreaks doctrinal havoc when stretched to its logical boundaries. In Major v. Treen, ${ }^{166}$ black legislators were intentionally excluded from a critical meeting during which white legislators revised Louisiana's congressional districting map. ${ }^{167}$ The meeting resulted in a plan that contained no majority-black congressional districts, despite a compact black population in the city of $\mathrm{N}$ ew O rleans sufficiently numerous to create such a district. ${ }^{168} \mathrm{~A}$ three-judge court found the whites-only meeting at which the districting plan was created to be probative of an intent to dilute black voting strength. ${ }^{169}$ U nder Abrams, however, the exclusion of these black legislators might be legally inconsequential because even if they or their proxies attended the meeting, their successful advocacy for a black district might be proof of an illegal gerrymander to aid black voters. ${ }^{170}$

Treen is instructive on another score. The state legislators who attended the whites-only meeting - and the governor who refused to sign an earlier redistricting plan containing a black district-were all actors who possessed the power to determine the outcome of the legislation. M inority legislators in A brams, even with the backing of the J ustice Department and A CLU, were simply not similarly situated to these lawmakers who, in the final analysis, controlled the process of redistricting. White members of the L ouisiana state legislature seemed to understand this, even if the Court in A brams could not. A s one participant in the whites-only meeting discussed in Treen confessed:

[T]he feeling in the meeting was that the one group, the one [constituency] group that was not going to come out of the session satisfied was going to be the blacks. The reason for that was that with all of the competing interests... there was probably going to be virtually no way to satisfy the black members of the Legisla-

\footnotetext{
166. 574 F. Supp. 325 (E.D. La. 1983).

167. See id. at 334 .

168. See id. at 334-36.

169. See id. at 355 n.39 (declining to draw an inference of intentional discrimination but considering the totality of the evidence in finding a dilution of the black vote).

170. U nder M iller's predominance test, the black district's relative compactness would not preclude a finding of unconstitutionality. See Miller v. Johnson, 515 U.S. 900, 915 (1995) (" $[P$ ]arties alleging that a State has assigned voters on the basis of race are neither confined in their proof to evidence regarding the district's geometry and makeup nor required to make a threshold showing of bizarreness.").
} 
ture... insofar as creating a majority black district [was concerned] . . . They [minority legislators] didn't have enough votes. ${ }^{171}$

J ustice 0 'C onnor, who cast the deciding vote in the 5-4 A brams decision, had previously recognized the fundamental distinction between acts of a majority intended to benefit a politically weaker minority and acts of a majority that evoke shades of self-dealing. ${ }^{172}$ In City of Richmond v. J .A. Croson Company, the distinction was a basis for invalidating a minority contracts set-aside program passed by a majority-black city council. ${ }^{173}$ In contrast, A brams failed to heed this distinction in invalidating the two-district plans passed by the majority-white Georgia A ssembly to benefit black voters who were a minority within the state. The impression created by the Court is that when whites are in the minority they will be entitled to greater protection under the Fourteenth A mendment than blacks will be when blacks occupy the same position. ${ }^{174}$

The rule of A brams presents still another doctrinal paradox. For nearly three decades, courts have looked to the responsiveness of white elected officials to determine whether minority voters have proven vote dilution in violation of either the Constitution ${ }^{175}$ or the $\mathrm{V}$ oting R ights A ct. ${ }^{176} \mathrm{~N}$ on-responsiveness or minimal responsiveness constituted evidence that minorities had less opportunity to partici-

171. $574 \mathrm{~F}$. Supp. at 334 (alterations in original) (emphasis added).

172. See City of Richmond v. J.A. Croson Co., 488 U.S. 469, 495-96 (1989) (noting that a majority-black city council's passage of a contract set-aside program implicated "[t]he concern that a political majority will more easily act to the disadvantage of a minority based on unwarranted assumptions or incomplete facts").

173. See id. at 511.

174. J ustice $\mathrm{O}$ 'Connor's selective application of the distinction she recognized in Croson is a classic illustration of what Professor Derrick Bell has called "interest-convergence": white support for black interests when whites stand to benefit. See Derrick A. Bell, J r., Brown v. B oard of Education and the Interest-Convergence Dilemma, 93 HARV. L. REV. 518, 524-25 (1980) (discussing the economic and political motives for white support of desegregation).

175. See, e.g., White v. Regester, 412 U.S. 755, 767 (1973) (holding that a Democratic nominating organization did not "exhibit good-faith concern for the political and other needs and aspirations of the Negro community"); Zimmer v. McK eithen, 485 F.2d 1297, 1305 (5th Cir. 1973) (including "the unresponsiveness of legislators to their [minorities'] particularized interests" among the panoply of factors to be considered in determining unconstitutional vote dilution), aff'd sub nom. E ast Carroll Parish Sch. Bd. v. Marshall, 424 U .S. 636 (1976) (per curiam).

176. 42 U.S.C. § 1971 (1994). See also S. REP. No. 97-417, at 29 (1982) (stating that "significant lack of responsiveness on the part of elected officials to the particularized needs of the members of the minority group" may, in some cases, constitute evidence of vote dilution in violation of section 2 of the $V$ oting $R$ ights $A$ ct). 
pate in the political process than whites. ${ }^{177} \mathrm{~A}$ brams invites a head-on collision with traditional vote dilution analysis by employing state efforts to respond to black interests as evidence of a violation of the Fourteenth A mendment. The inevitable message conveyed to white government officials is that responsiveness matters less. W orse still, state and local governments are now placed in the precarious position of determining how much responsiveness will suffice to mitigate the claims of vote dilution by racial minorities and how much responsiveness will violate the Constitution. ${ }^{178}$

Some may be inclined to apply a simple test of even-handedness to the evidentiary problem of minority group advocacy in the redistricting context. Thus, if courts are free to examine the legislative process for evidence of discriminatory intent in other contexts, as where whites are accused of invidiously discriminating against minorities, surely it is fair to do the same in cases like A brams. B ut the Court in A brams dispensed with any pretense of even-handedness by failing to require that the plaintiffs demonstrate the state's intent to harm an identifiable group-normally a threshold requirement for application of strict scrutiny to facially neutral legislation which allegedly violates the $\mathrm{E}$ qual Protection Clause. ${ }^{179} \mathrm{M}$ oreover, nothing in A brams curtails white participation in the very heart of the two-party process-redistricting. White voters remain free to call for the creation of districts that reflect their various interests: conservative districts, Christian fundamentalist districts, farming districts. The Court has never suggested that this kind of activity is constitutionally suspect, though a good argument can be made that many of the ideo-

177. See Z immer v. M cK eithen, 485 F.2d 1297, 1305 (5th Cir. 1973).

178. For an odd twist on this problem, see D ebra W est, In M ount Vernon, B lack Woman is Rejected for Sake of Diversity, N.Y. TIMES, Mar. 25, 1998, at B1. The city of M ount Vernon, $\mathrm{New}$ Y ork, is predominantly black, and four members of its five-member City Council are black. The lone white member on the council resigned, and D emocratic Party leaders must now appoint an interim replacement. Fearing a possible suit by white voters calling for the dismantling of the city's at-large, citywide election system-a system which permits a cohesive majority to capture all seats- party officials publicly announced that they were seeking a white to fill the vacancy. See id. Three blacks seeking the position were told that they were unlikely to receive it because of their race. See id. B ecause M ount Vernon has made racial diversity-and therefore race- a principal criterion in its selection process, it may be sued under A brams for its efforts to be responsive to the city's white community. See M iller v. J ohnson, 515 U .S. 900 , 916, 920 (1994) (stating that strict scrutiny is triggered where race is the predominant criterion for decisionmaking).

179. See Sheila Foster, Intent and Incoherence, 72 TUL. L. REV. 1065, 1161-67 (1998) (arguing that, despite the Court's general recognition of the need for judicial restraint in the politically-charged realm of redistricting, the Court's recent racial gerrymandering cases unjustifiably relax the requirement of specific discriminatory intent). 
logical interests that whites are permitted to employ in districting are rooted in a hostility toward blacks. ${ }^{180}$ Thus, the constraint on black advocacy imposed by the Court in A brams is unique and debilitating.

180. See supra note 156 and accompanying text. This is especially true of R epublican conservative congressional districts. To a considerable degree, the modern R epublican Party, particularly its southern wing, was born of white resentment of the Democrats' embrace of civil rights and black voters. See Carmines \& H uckfeldt, supra note 80, at 121-34. Carmines and H uckfeldt explain that the 1964 presidential election "marked a restructuring of A merican political parties around racial issues." Id. at 121. It was that year that L yndon J ohnson firmly allied the D emocratic Party with civil rights and the fortunes of black voters while his R epublican opponent, Barry Goldwater, choose the opposite route. See id. A s a consequence, R epublicans- who throughout the 1940s and 1950s were more liberal on issues of race than congressional Democrats-dramatically shifted their position and became the party of "white racial disaffection." Id. at 121, 130. See also James M. GLASeR, RaCe, CAmpaign Politics, and THE REALIGNMENT IN THE SOUTH 5 (1996):

When the K ennedy and J ohnson administrations started to take a more active role in advancing civil rights in the South and when Barry Goldwater partially based his presidential campaign in 1964 on his opposition to the Civil Rights A ct of 1964, a polarization of the national parties over race began to set.

Republican political strategists urged their party to exploit whites' racial alienation from the Democratic Party. See id. at 6 (noting that Republican political strategist Kevin Phillips "enthusiastically" urged this tactic). "Today even southern D emocrats are less conservative on matters of race than the Senate Republican party as a whole." Carmines \& Huckfeldt, supra note 80 , at 121 .

The alienation of white voters from the D emocratic Party just as the party began to embrace black civil rights has led to a racial polarity in the A merican two-party structure that transcends class:

What are the political consequences of the D emocratic party's reliance on black voters? White voters are frequently unwilling to support a party that depends heavily upon black support, and the decline in white support for Democratic presidential candidates has been most pronounced among working-class whites. Thus class differences in party support among whites have narrowed as racial differences have increased .... [T ] ] mo milization of blacks by the D emocratic party has fundamentally altered its status as the working-class party in A merican politics. A nd at least in this regard, the $\mathrm{N}$ ew $\mathrm{D}$ eal party system has been significantly transformed.

Id. at 130.

E ven scholars who contend that race in its explicit form has disappeared as a partisan issue concede that it continues to be intertwined with a more general ideological divide between R epublicans and $D$ emocrats and that the voting patterns created by explicitly racial issues beginning in 1964 have not disappeared. See LA WRENCE, supra note 8, at 73. See also K evin Sack, South's E mbrace of G.O.P. is N ear a Turning Point, N.Y. TIMES, M ar. 16, 1998, at A 1 (noting that a rejection of the $D$ emocratic Party's positions on both economics and race have resulted in R epublican gains in the South). Thus, courts should not presume racial neutrality in the creation of R epublican conservative districts. N ot only does the majority party in such districts tend to be racially homogeneous, see B. D rummond A yres, J r., Political B riefing, N.Y. TIMES, A pr. 17,1998 , at $A 16$ (noting only 1 in every 10 blacks identifies himself as a R epublican), but it also promotes a set of issues which have an explicitly racial genesis and a disparate racial impact. See, e.g., Donald R. Kinder \& LynN M. SAnders, Divided By Color 208 (1996) ("[D ]ifferences between the parties on race set in motion by the events of 1964 have, if anything, hardened over the succeeding years." ); G irardeau A. Spann, A ffirmative A ction and D iscrimination, $39 \mathrm{H} \mathrm{OW}$. L.J . 1, 68 (1995) (characterizing opposition to affirmative action, a stan- 
This constraint, moreover, is entirely unnecessary to the Court's stated objective in its wrongful gerrymandering cases, which is to "mak[e] extreme instances of gerrymandering subject to meaningful judicial review." ${ }^{181}$ But how extreme could the gerrymandering in Georgia have been if, as the majority in Miller conceded, "by comparison with other districts the geometric shape of the Eleventh D istrict may not seem bizarre on its face" ? ${ }^{182}$ In the absence of a more coherent measurement rooted in the realities of the redistricting process and the goal of two-party stability, the Court's inquiry into the predominant purpose of the legislature's redistricting was simply one step further into the "political thicket." But, as will be shown below, the Court's journey from max-black to min-black may be more harmful to the two-party political process as a whole than helpful to the plaintiffs who sought the remedy of eliminating the majority-black districts in Georgia. That harm is inextricably linked to the Court's misconceptualization of the plaintiffs' injury in the racial gerrymandering cases.

\section{The Deference-InJuRy NeXus: A BLACK A pOStasy OF THE TWO-PARTY PARA DIGM?}

Courts have long grappled with the problem of the "political thicket" and have been vexed by the inconsistent outcomes that have ensued from judicial regulation of the electoral process. ${ }^{183}$ The initial constraint on judicial intervention, the political question doctrine, has long ago faded into irrelevance in matters affecting the fundamental right to vote. ${ }^{184}$ Thus, the Court has recognized the justiciability of

dard conservative position, as "a form of perpetuated racial discrimination because opponents are willing to freeze the illegitimate gains that whites have made over minorities as a result of past racial discrimination").

181. M iller v. Johnson, 515 U.S. 900, 929 (1995) (O 'Connor, J ., concurring).

182. Id. at 917.

183. Compare Tashjian v. R epublican Party of Conn., 479 U .S. 208 (1986) (finding that an alliance of R epublicans and independent voters did not threaten political stability), with Timmons v. T win Cities A rea N ew Party, 117 S. Ct. 1364 (1997) (concluding that an alliance of the New Party and Democrats was harmful to the state's interest in political stability); compare also White v. R egester, 412 U .S. 755, 765-70 (1973) (finding racial vote dilution where an atlarge system of elections existed in conjunction with other discriminatory electoral devices and a pervasive history of racial discrimination in Texas), with City of M obile v. Bolden, 446 U.S. $55,69-74$ (1980) (finding no dilution despite the existence of many of the same factors found to be sufficient in White).

184. See, e.g., Davis v. Bandemer, 478 U.S. 109, 118-27 (1986) (reviewing the Court's treatment of the political question doctrine in cases involving the right to vote and concluding that the doctrine did not apply to Indiana Democrats' claim of excessive partisan gerryman- 
claims involving the exclusion of racial minorities from party primaries, ${ }^{185}$ population inequality in apportionment, ${ }^{186}$ and minority and partisan vote dilution. ${ }^{187}$ These cases had two characteristics in common. First, they involved an alleged injury to voting. Second, the remedy in each was circumscribed so as not to disturb two-party stability and the model of party participation that J ustice $O$ 'Connor presented in Davis. ${ }^{188}$ Abrams-which had neither of these two features-suggests a relationship between them. Where the Court is not limited to remedying an injury to voting, its decisions are more likely to unsettle two-party stability; in the absence of a tangible harm, it cannot rationally gauge the amount of deference that should be accorded state legislatures' political judgments.

This consequence flows from the ingrained two-party bias of our political system. Even where a state's interest in two-party politics is not directly at issue in a case, it is almost always implicated. Political participation does not occur in an abstract vacuum but rather in the two-party system that the states have been allowed to perpetuate. Thus, the failure to defer to state legislative choices in the redistricting realm-choices which are presumptively consistent with twoparty politics- may not only defeat the particular redistricting plan at issue but may also harm the underlying two-party process. G iven the omnipresent state interest in two-party political stability, this Part asks whether the lack of deference in A brams was a function of the intangible nature of the injury alleged by the plaintiffs and whether there was a corresponding harm to the two-party process. This inquiry requires, first, a more detailed examination of the nature of the injury claimed by the plaintiffs in A brams compared to the injuries of other plaintiffs on whose behalf the Court has intervened and, second, an evaluation of how the Court's indulgence of the plaintiffs might threaten two-party stability.

dering). The political question doctrine, which is driven by separation of powers concerns, requires that federal courts abstain from hearing a case in a variety of circumstances which would unduly stretch their institutional competence, such as where resolution of the issue is expressly committed to another branch of the government. See id. at 121.

185. See infra text accompanying notes 204-205.

186. See infra text accompanying notes 206-208.

187. See infra text accompanying notes 209-211; D avis, 478 U .S. 109.

188. See D avis, 478 U .S. at 144-45 (O 'Connor, J ., concurring). 


\section{A. A brams: What K ind of Injury? What K ind of E quality?}

A Ithough the A brams opinion did not identify the injury to the plaintiffs who objected to the Georgia redistricting that would have created three black districts, it implicitly reaffirmed the Miller Court's view that "[w] hen the State assigns voters on the basis of race, it engages in the offensive and demeaning assumption that voters of a particular race, because of their race, 'think alike, share the same political interests, and will prefer the same candidates at the polls."' ${ }^{189}$ M iller, in turn, was a reaffirmation of the Court's logic in its landmark reverse-racial gerrymandering decision, Shaw v. Reno. ${ }^{190}$ Shaw explained that the harms of race-based districting include its resemblance to apartheid, its perpetuation of racial stereotypes, its potential to create racial hostility and exacerbate racial bloc voting, and its implicit message to elected officials that they should represent only the interests of the racial group for whom a district has been created. ${ }^{191}$ In U nited States v. H ays, ${ }^{192}$ J ustice O 'C onnor termed these injuries "special representational harms."

The harms that the Court attributed to majority-minority districts such as G eorgia's Second and E leventh can be substantiated by neither the casual nor the close observer. To the extent such districts stereotyped voters, these voters were free to break the mold by voting contrary to the government's allegedly stereotypical expectations. A ny resemblance these districts had to apartheid was belied by the fact that they were two of the most integrated districts in the country, ${ }^{194}$ and the resulting election of two additional black representatives made G eorgia's congressional delegation more, not less, representative of Georgia's population. ${ }^{195}$ If such districts created racial

189. M iller v. Johnson, 515 U .S. 900, 911-12 (1995) (quoting Shaw v. R eno, 509 U .S. 630, 647 (1993)).

190. 509 U .S. 630 (1993).

191. See id. at 647-48.

192. 515 U .S. 737 (1995).

193. Id. at 745 .

194. The Second D istrict was $42 \%$ white, while the Eleventh was $34 \%$ white. See REEVES, supra note 28 , at 96 . See also M cD onald, supra note 28 , at 139 (noting that majority-minority congressional districts in the South are among the most integrated in the country, containing an average white population of $45 \%$ ).

195. Blacks constitute approximately $28 \%$ of Georgia's population. See STATISTICAL A BSTRACT supra note 102, at 34. A fter A brams, which left only one majority-black congressional district, blacks hold majority status in only $9 \%$ of the state's 11 congressional districts. Prior to A brams, during which three black-majority districts existed, blacks had achieved rough parity with their population numbers, controlling $27 \%$ of the state's congressional districts. 
hostility-a prediction for which the Court provided no empirical support-one must ask whether that hostility is simply the expected anger of whites when they are placed in the unaccustomed position of sharing power with racial minorities. ${ }^{196}$ This may be an injury of sorts, but, far from recognizing such a harm, the Constitution protects unpopular minorities from the irrational hostility of a majority. ${ }^{197}$

A s for the notion that the Second and Eleventh D istricts would exacerbate racial bloc voting-another unsupported assertion by the Court-the purpose of section 2 of the Voting Rights A ct is to address this very phenomenon where it unfairly disadvantages minority voters. B ecause the Court has stressed that a Shaw/A brams claim that a "reapportionment plan rationally cannot be understood as anything other than an effort to segregate citizens...." is "analytically distinct" from a vote dilution claim, ${ }^{198}$ its argument becomes fatally bootstrapped when it adverts to racial bloc voting-an element of a vote dilution claim-as the injury from which it is seeking to protect plain-

196. See generally Charles R. Lawrence III, The Id, the Ego, and Equal Protection: Reckoning with Unconscious Racism, 39 STA N. L. REV . 317, 372 (1987) (arguing that "whites are not accustomed to seeing blacks in positions of authority or power," and that blacks' historical exclusion from such positions has been "rationalized" by the stereotype that they are not suited for these roles).

Indeed, the inevitable result of recognizing a claim of the Shaw/A brams variety is the whetting of appetites for white racial dominion of the political process. A fter the Supreme Court struck down North Carolina's Twelfth Congressional District as an unconstitutional racial gerrymander in Shaw v. H unt, 517 U .S. 899 (1996), the N orth Carolina General A ssembly redrew the district, reducing its black voting-age population to only $43 \%$. See Cromartie v. H unt, No. 4:96-CV-104-BO (3), 1998 U.S. Dist. LEXIS 7767, at *8 n.2 (E.D.N.C. A pril 14, 1998), probable juris. noted, 1998 WL 407142,*1 (U .S.N.C. Sept. 29, 1998). V oters in the T welfth $D$ istrict nevertheless again challenged its composition as an unconstitutional racial gerrymander. A three-judge panel, with Circuit J udge Ervin dissenting, sustained this challenge because the new district continued to be "unusually shaped," id. at $* 25$, and because North Carolina appeared in certain precincts to maximize the number of black voters rather than the number of registered D emocrats. See id. at *28. J udge E rvin, however, aptly observed:

While this may not be dispositive of the question whether race was the predominant factor in the legislature's redistricting plan, the fact that all of North Carolina's congressional districts are majority-white at the very least makes the Plaintiffs' burden, which is already quite high, even more onerous. $\mathrm{H}$ ad the legislature been predominantly influenced by a desire to draw D istrict 12 according to race, I suspect it would have created a district where more than $43 \%$ of the voting-age population was black.

Id. at *38 (Ervin, J., dissenting). If the Supreme Court sustains the result in Cromartie, the Shaw/A brams doctrine will almost certainly become an invitation to a new "lily-whitism" in A merican politics.

197. See, e.g., City of Cleburne v. Cleburne Living Ctr., 473 U .S. 432, 450 (1985) (striking down a special permit requirement for maintenance of a home for the mentally retarded because the requirement rested on "irrational prejudice").

198. Shaw v. R eno, 509 U.S. 630, 652 (1993). 
tiffs. In any event, given that voters in majority-minority districts are more willing to support white candidates than are voters in majoritywhite districts to support minorities, ${ }^{199}$ it seems utterly perverse to suggest that districts in which blacks are a voting majority will fan racial bloc voting but districts in which whites are in the majority will not. Finally, the Court's concern that members elected from majority-black districts will feel loyalty only to their black constituents directly contradicts its embrace of formal equality in Davis, where it maintained that "[a]n individual or a group of individuals who votes for a losing candidate is usually deemed to be adequately represented by the winning candidate and to have as much opportunity to influence that candidate as other voters in the district." ${ }^{200}$

Given the notable vagueness of the claims raised by the Shaw/A brams plaintiffs, it is unsurprising that commentators have questioned whether such plaintiffs meet A rticle III's standing requirement of an injury-in-fact. ${ }^{201} B$ ut the ethereal nature of the injury claimed by the Abrams plaintiffs poses another problem for courts: since there is no way to be clear about the nature of the injury, courts cannot be clear about what kind of equality interests judicial intervention will serve. Consequently, they are also unable to rationally situate these claims within the established party structures that states have been permitted to favor.

The A brams plaintiffs did not state a claim of protective democracy; unlike the plaintiffs in Davis, these plaintiffs did not claim that they possessed inadequate political influence. ${ }^{202}$ Nor were they seeking formal equality of the "one person, one vote" sort, since they possessed unfettered access to the polls and to participation in the politi-

199. See M CD onald, supra note 28 , at $139-41$ (comparing levels of white success in black districts with white voting for minority candidates in white districts). M CD onald concludes:

The voting trends in G eorgia, L ouisiana, and M ississippi [states which had created black congressional districts under the $\mathrm{V}$ oting $\mathrm{R}$ ights $\mathrm{A} \mathrm{ct}$ ] undermine the argument that highly integrated majority-minority districts have increased polarization. To the contrary, they hold out the promise, perhaps for the first time in the South's troubled history, of meaningful biracial politics.

Id. at 140-41 (footnotes omitted). H owever, M cD onald also observes increases in the willingness of white voters in majority-minority districts to support minority candidates. See id. at 140.

200. 478 U.S. 109, 132 (1986).

201. See, e.g., Pamela S. K arlan, Still H azy A fter All These Years, 26 CuM B. L. Rev. 287, 294-95 (1996) (noting that "all three prongs of the traditional standing inquiry pose problems for wrongful districting claims"); M elvyn R. Durchslag, U nited States v. Hays: A n E ssay On Standing To Challenge Majority-M inority Voting Districts, 65 U. CIN. L. REV. 341, 356-59 (1997).

202. See supra note 47 and accompanying text (describing claims of protective democracy). 
cal process. Instead, the A brams plaintiffs succeeded in persuading the Court to disturb formal equality by making it more difficult for blacks to exert influence on the redistricting process than it is for other groups to do so. Thus, the minimal equality that the Court seemed to guarantee in Davis - the "chance to effectively influence the political process" 203 - was withheld from black voters in $\mathrm{G}$ eorgia. $B$ ut where groups do not enjoy this minimal equality, what is their incentive to participate in the two-party process? While past judicial experience had been limited to claims that required a balancing of substantive and formal equality, A brams involved the elimination of both. Some discussion of the Court's earlier ballot box cases will be helpful.

Prior to Shaw, an injury to voting was a necessary, though perhaps not always sufficient, pre-condition to obtaining a remedy for state action affecting the electoral process. In the white primary cases, ${ }^{204}$ black plaintiffs complained that they were excluded on the basis of race from participating in critical portions of the candidate selection process. R ejecting arguments that private organizations rather than the state were responsible for the processes at issue, the Court ultimately sustained the plaintiffs' persistent challenges because the private mechanism for choosing candidates had become an integral part of the state electoral process. ${ }^{205}$ The plaintiffs in A brams and its forerunners did not allege exclusion from the electoral process on the basis of race.

203. D avis v. B andemer, 78 U .S. 109, 133 (1986).

204. Nixon v. Herndon, 273 U .S. 536, 541 (1927) (holding that Texas's blanket prohibition against $N$ egro participation in the $D$ emocratic Party primary violated the Fourteenth $A$ mendment); Nixon v. Condon, 286 U .S. 73, 88 (1932) (rejecting Texas's attempt to avoid the strictures of the Fourteenth A mendment by delegating the authority to determine qualifications for participating in party primaries to a State Executive Committee because such Committees become "the organs of the State itself, the repositories of official power"); G rovey v. Townsend, 295 U.S. 45, 53 (1935) (finding no state action, and hence no violation of the Fourteenth A mendment, where a Negro voter was excluded from a Texas D emocratic primary based on resolution of $D$ emocratic Party Convention of Texas permitting only white citizens to participate in party primaries); Smith v. A llwright, 321 U.S. 649, 663-64 (1944) (overruling G rovey and holding that political parties act as state agencies when they follow statutory mandates to select party nominees for the general election); Terry v. A dams, 345 U .S. 461, 463, 469 (1953) (finding unlawful state exclusion of Negroes from the J aybird Democratic Party, a nominally private association, where that party's primary almost invariably dictated the winner of the regular $D$ emocratic primary).

205. See Terry, 345 U .S. at 469. 
In Reynolds v. Sims, ${ }^{206}$ the Court held that states' malapportionment affording greater representation to sparsely populated rural areas than to more populous urban and suburban districts violated the Fourteenth A mendment's implicit command of "one person, one vote." ${ }^{207}$ The Court wrote:

[I]f a State should provide that the votes of citizens in one part of the State should be given two times, or five times, or [ten] times the weight of votes of citizens in another part of the State, it could hardly be contended that the right to vote of those residing in the disfavored areas had not been effectively diluted. ${ }^{208}$

The plaintiffs in A brams and its forerunners did not allege, nor could they have proved, quantitative vote dilution.

Reynolds provided the theoretical framework for another type of vote dilution claim, racial vote dilution. In this category of cases, black plaintiffs claimed that at-large electoral structures combined with racial bloc voting and other demographic and social disadvantages to effectively minimize or cancel out their voting potential. ${ }^{209}$ The Court has provided a constitutional remedy in such cases where plaintiffs have demonstrated that "the political processes leading to nomination and election were not equally open to participation by the group in question - that its members had less opportunity than did other residents in the district to participate in the political processes and to elect legislators of their choice." ${ }^{210}$ In A brams and its forerunners, such as Shaw, the plaintiffs conceded that they could not make out a claim of racial vote dilution, for each of the redistricting

\footnotetext{
206. 377 U .S. 533 (1964).

207. See id. at 568 .

208. Id. at 562.

209. See, e.g., Whitcomb v. Chavis, 403 U .S. 124 (1971) (rejecting an equal protection challenge to at-large elections because plaintiffs were unable to demonstrate that their votes were canceled out or diluted on account of race rather than political affiliation); W hite v. R egester, 412 U .S. 755, 766 (1973) (sustaining a constitutional challenge to at-large elections upon finding that the processes of nominating and electing legislators were not fully open to the group in question such that it was unable to exert the political influence that its numbers suggested it had); City of M obile v. B olden, 446 U .S. 55, 66 (1980) (plurality opinion) (imposing a discriminatory intent requirement on F ourteenth $A$ mendment challenges to at-large electoral systems); R ogers v. L odge, 458 U .S. 613, 620-22 (1982) (upholding district court's determination that although at-large system was not created with a discriminatory purpose, it was maintained with such a purpose and thus violated the Constitution).
}

210. White v. R egester, 412 U .S. 755, 766 (1973) (citing W hitcomb v. Chavis, 403 U .S. 124, 149 (1971)). 
plans challenged in these cases left whites overrepresented in relation to their statewide populations. ${ }^{211}$

Cases involving political gerrymanders, ${ }^{212}$ ballot access restrictions, $^{213}$ and assorted restrictions on the exercise of the franchise ${ }^{214}$ have all similarly involved an alleged injury to voting. Thus, Shaw/A brams claims are clearly in a category of their own. This distinction, in and of itself, does not detract from the validity of A brams if one believes that racial stereotyping is a harm distinct from impediments to the right to vote. However, equal protection analysis of fundamental rights recognizes substantial infringements on the right to vote as being at least as serious as the stereotyping identified in Shaw $^{215}$-yet the remedies afforded Shaw/A brams plaintiffs are much more deferential than those afforded plaintiffs in cases involving an actual injury to voting. M ore specifically, the remedies in the latter cases have tended to be circumscribed so as to preserve the states' interest in two-party political stability while the same is not true of A brams and its kin.

The remedy in the white primary cases was to open up the political processes to blacks. ${ }^{216}$ W hile this undoubtedly caused some white southerners to move from the Democratic Party to the more racially conservative $^{217}$ R epublican Party, the remedy could hardly be said to

211. The Court in Shaw went to great lengths to distinguish the facts of the case before it from cases involving vote dilution. See, e.g., Shaw v. Reno, 509 U.S. 630, 652 (1993) (distinguishing U nited J ewish O rgs. of Williamsburgh, Inc. v. Carey, 430 U .S. 144 (1977)). But this effort only underscores the fact that prior to Shaw the Court had always required an injury to voting in cases involving state regulation of the electoral process.

212. See e.g., D avis v. B andemer, 478 U .S. 109, 113 (1986).

213. See supra note 32 and accompanying text.

214. See, e.g., R ichardson v. R amirez, 418 U .S. 24, 26 (1974) (involving disenfranchisement of convicted felons); Kramer v. U nion Free Sch. Dist. No. 15, 395 U.S. 621, 622 (1969) (involving restrictions on the right to vote in school board elections).

215. See, e.g., D unn v. Blumstein, 405 U .S. 330, 336 (1972) (applying strict scrutiny to state residence durational requirements limiting the franchise); Bullock v. Carter, 405 U.S. 134, 144 (1972) (holding that equal protection analysis requires strict scrutiny of legislative classifications which interfere with the right to vote). A lthough subsequent decisions have shifted the Court's focus from the traditional trinity of strict scrutiny, intermediate scrutiny and rational basis review to a more flexible "undue burden" approach, severe restrictions on the right to vote continue to be strictly scrutinized. See A lan Brownstein, $\mathrm{H}$ ow Rights A re Infringed: The Role Of Undue Burden A nalysis In Constitutional Doctrine, 45 HASTINGS L.J. 867, 917-20 (1994).

216. See Terry v. A dams, 345 U .S. 461, 470 (1953) (invalidating whites-only primary elections).

217. This A rticle employs the terms "racially conservative" or "racial conservative" to refer to whites who, consciously or unconsciously, are resistant to black equality and who therefore 
harm two-party stability. The remedy in equal population cases such as R eynolds v. Sims has been to ensure population equality to the extent practicable, a result not on its face inconsistent with the vibrancy of states' two-party systems. ${ }^{218}$ The dismantling of at-large voting systems that is the most common remedy in racial vote dilution cases aids two-party stability since "[t]he very essence of districting is to produce a different-a more 'politically fair'-result than would be reached with elections at large, in which the winning party would take $100 \%$ of the legislative seats." ${ }^{219}$ Indeed, except in cases where the rights of political parties or independent candidates have been at issue, ${ }^{220}$ none of the remedies afforded in cases involving an actual injury to voting has had a direct effect on the states' interest in maintaining two-party stability. ${ }^{221} \mathrm{M}$ oreover, even in those cases involving minor political parties or independent candidates, cases which di-

support policies which have the effect of grandfathering historical white privilege while impeding black progress.

218. See K archer v. D aggett, 462 U .S. 725, 740 (1983) (stating that population deviations in congressional apportionment may be permissible in order to "avoid[] contests between incumbent R epresentatives"). The protection of incumbents, the overwhelming majority of whom belong to the two major parties, is a central means of protecting two-party stability. See supra note 35 and accompanying text.

219. G affney v. Cummings, 412 U .S. 735, 753 (1973). The ongoing debate over the extent to which black districts harm the Democratic Party by taking black voters out of the districts of moderate white $D$ emocrats is obviously relevant to, and perhaps detracts somewhat from, this proposition. But there is a difference between a remedy that changes the racial composition of a state's representatives, which the creation of black districts may do, and one which encourages a group's abandonment of the two-party process, which the failure to create black districts may do.

220. See, e.g., A nderson v. Celebrezze, 460 U .S. 780, 801 (1983) (invalidating O hio's early filing deadline for independent candidates where the state's "asserted interest in political stability amount[ed] to a desire to protect existing political parties from competition ... . generated by independent candidates who have previously been affiliated with the party"); William v. R hodes, 393 U .S. 23, 25 (1968) (sustaining an equal protection challenge to 0 hio laws that rendered it "virtually impossible" for minor parties to gain access to the state ballot for selection of electors pledged to presidential candidates).

221. The Supreme Court's treatment of political patronage is not to the contrary. A Ithough it does not involve voting per se, conditioning public employment on one's political affiliations "prevents support of competing political interests [and] thus tips the electoral process in favor of the incumbent party. . .." E Irod v. B urns, 427 U .S. 347, 356 (1976). E ven when the Court has outlawed such practices, it has stated:

[W] ]e are not persuaded that the elimination of patronage practice... will bring about the demise of party politics. Political parties existed in the absence of active patronage practice prior to the administration of A ndrew Jackson, and they have survived substantial reduction in their patronage power through the establishment of merit systems.

Id. at 369. 
rectly challenge the two-party paradigm, the Court has consistently recognized this interest. ${ }^{222}$

A dmittedly, the interest in two-party stability has not been asserted in all cases involving an actual injury to the right to vote. From the standpoint of doctrinal coherency, however, the important question is whether the goals that one decision purports to facilitate can rationally coexist with the objectives of other decisions. Thus, whether or not two-party stability is asserted as a state interest in a given case, once the Court recognizes it as a significant interest-as it recently did in Timmons ${ }^{223}$-other decisions should not needlessly conflict with that interest. The Court has been able to intervene in the political process in cases involving actual injuries to voting without uprooting two-party stability because the injury requirement itself has limited the enterprise in which the Court has engaged. A brams, however, contains no such limitation and actually encourages exit from the two-party system by the same racial minorities whose participation would achieve the integrationist goals to which the Court purportedly aspires.

\section{B. A Remedy at What Price?: R acial Splintering of the Two-P arty Process}

To understand more fully how A brams effectively discourages blacks from participating in the two-party system, one must appreciate how they have functioned in that system in the past. Blacks have historically functioned as a party within a party. E ven during the era of limited black enfranchisement, blacks formed "satellite" or "parallel" parties to advance their interests within the two-party structure. These groups "revolve[] in the orbit of a major political party on the national level and run[] parallel with the state party to modify the practices of the regular party in light of their own goals and objectives." ${ }^{224}$ To counteract the movement of southern R epublicans to "lily-whitism" after the first R econstruction, blacks formed a parallel party known as the Black and Tan R epublicans. ${ }^{225}$ While sev-

222. See supra notes $32-34$ and accompanying text. See also Timmons v. Twin Cities A rea N ew Party, 117 S. Ct. 1364, 1374 (1997) ("The Constitution permits the M innesota L egislature to decide that political stability is best served through a healthy two-party system.").

223. See Timmons, $117 \mathrm{~S}$. Ct. at 1374.

224. Walton, Black POLitical Parties, supra note 31, at 80-81.

225. See id. at 64. A number of separate, pre-existing parties based in several states united under one umbrella to form the B lack and Tan R epublicans. See id. 
eral presidents, including Theodore Roosevelt and Warren G. $\mathrm{H}$ arding, sought the support of the B lack and T an R epublicans in securing party nominations, none was responsive to the Black and Tans' political agenda. ${ }^{226}$ Similar parallel parties existed within the D emocratic Party. The South Carolina Progressive D emocratic Party was a satellite partisan group formed by blacks in 1944, as blacks nationally were shifting their collective allegiance away from the party of Lincoln. ${ }^{227}$ The group's aims were to help reelect "Franklin D elano Roosevelt to a fourth term and to abolish the state's white primary," ${ }^{228}$ which effectively excluded blacks from voting in that oneparty state. ${ }^{229}$ The Progressive D emocrats were forerunners of what is perhaps the best known parallel party, the Mississippi Freedom D emocratic Party. ${ }^{230}$ The Freedom D emocrats challenged the segregated M ississippi delegation's credentials at the 1964 D emocratic National Convention, showcasing the need for voting rights legislation and speeding passage of the $V$ oting $R$ ights $A$ ct of $1965^{231}$

The $V$ oting $R$ ights $A$ ct's prohibition against vote dilution, ban on literacy tests, preclearance procedures for covered jurisdictions, and other enforcement mechanisms produced revolutionary change in the composition of the nation's electorate and legislative bodies. Between 1964 and 1988, the percentage of voting-age blacks registered to vote in the eleven southern states increased from $43.3 \%$ to $65.2 \%{ }^{232}$ B lack registration in the five states of the D eep South rose from $22.5 \%$ to approximately $65.2 \% .{ }^{233}$ The number of black elected

\footnotetext{
226. See id. at 65 .

227. See id. at 70 .

228. Id.

229. See id.

230. Seeid. at 80-81.

231. See id. at 92. Perhaps no moment of the 1964 D emocratic convention was more moving or memorable than the testimony of Fannie L ou Hamer, a M ississippi Freedom D emocratic Party member and a former plantation timekeeper, before the credentials committee. A fter testifying at length on national television about violent resistance to her party's efforts to register voters in $\mathrm{M}$ ississippi, $\mathrm{H}$ amer concluded:

A Il of this is on account we want to register, to become first-class citizens, and if the Freedom D emocratic Party is not seated now, I question A merica, is this A merica, the land of the free and the home of the brave where we have to sleep with our telephones off the hooks because our lives be threatened daily because we want to live as decent human beings, in A merica?

Kay MiLls, This LitTLe Light Of Mine: The Life Of FANNie Lou HAMER 120-21 (1993).

232. See Chandler $D$ avidson, The $V$ oting Rights A ct: $A$ B rief $H$ istory, in CONTR OVER SIES IN Minority Voting: The Voting Rights A CT in Perspective 43 (Bernard Grofman et al. eds., 1992).

233. Seeid.
} 
officials in the seven jurisdictions originally covered under the A ct's preclearance provisions rose from 100 in 1965 to 3,265 in $1989 .{ }^{234} \mathrm{In}$ the round of redistricting that produced the disputed districts in A brams, states attempting to comply with the strictures of the $V$ oting Rights A ct created new majority-black districts in Florida (three), Georgia, North Carolina, Texas (two each), A labama, Louisiana, Maryland, New Y ork, Pennsylvania, South Carolina and Virginia (one each). ${ }^{235}$ Thus, during the three decades between the passage of the $V$ oting R ights A ct and the decision in Shaw v. Reno, the Supreme Court's ballot-box jurisprudence had evolved in a manner that allowed the D emocratic Party to accommodate black voters' interest in sharing power. Where racial bloc voting denied black voters the equal opportunity to elect the candidate of their choice, the federal judiciary could legitimately intervene to order a remedy, most often majority-minority districts, on their behalf..$^{236}$ The Court appeared to recognize, however, that the voluntary creation of a majorityminority district occasioned no federal intervention because a test based on a district's racial identity would subject all state districting decisions to judicial interference. ${ }^{237}$

In overwhelming numbers, black voters and elected officials made the Democratic Party their political home. ${ }^{238}$ To be sure, the marriage between blacks and Democrats is hardly perfect. A s black support for the Democrats has increased, white support has eroded, putting D emocrats at risk of becoming the party of blacks and white liberals-a coalition usually not large enough to prevail in a state or

234. See id.

235. See Frank R. Parker, Shaw v. R eno: A Constitutional Setback for M inority Representation, PS: POL. SCI. \& POL., M ar. 1995, at 47, 49 n.1.

236. See Pamela S. K arlan, All O ver the M ap: The Supreme Court's Voting Rights Trilogy, 1993 Su p. CT. R E V. 245, 266-68 (discussing the Court's emphasis on bloc voting as one of three preconditions of a vote dilution inquiry under section 2 of the $V$ oting $R$ ights $A$ ct).

237. See id. at 268. K arlan argues that the Court's pre-Shaw decisions appear to appreciate that:

[A ]II districts have a racial identity, at least in the sense that their racial composition can be readily described and readily perceived by any politically knowledgeable observer. Thus, it is impossible to say that states must have a justification for consciously drawing racially identifiable districts without subjecting every state districting choice to federal review. Id.

238. See KINDER \& SANDERS, supra note 180, at 208, 213 fig.8.2 (noting that in 1964 blacks moved almost unanimously to the D emocratic party and that in the 1992 presidential election they gave nearly $90 \%$ of their votes to the D emocratic candidate). 
national election. ${ }^{239}$ Fearful of this prospect, D emocratic leaders, often to the consternation of blacks, have attempted to move the party closer to the Republicans and to project an image that belies black control or ultra-liberalism. ${ }^{240}$ Indeed, black and white Democrats have split over whether the creation of majority-minority districts helps or hurts the Democratic Party. ${ }^{241}$ Notwithstanding such disputes, however, prior to the Shaw/A brams line of authority, the Court's voting rights cases gave the Democratic Party leeway to accommodate the electoral aspirations of its black constituents if it wished to do so. This may help to explain why calls for the formation of a black third party did not take hold during the post- $V$ oting $R$ ights A ct, pre-Shaw/A brams period. B lacks were, for the first time since Reconstruction, sharing political power within a major party, and

239. See Carmines \& H uckfeldt, supra note 80 , at 132-33.

240. See KINDER \& SANDERS, supra note 180, at 208 (noting that President Clinton, in his 1992 campaign, attempted to project a moderate image by demonstrating interest in welfare reform and crime control); see also TOM WICKER, TRA GIC FAILURE: RA CIA L INTEGRATION IN A MERICA 52-53 (1996) (arguing that the conservative takeover of the R epublican Party in 1964 and George Wallace's two presidential campaigns have not only transformed the Republican Party but have also forced the D emocratic Party "to the right").

That $D$ emocrats are self-conscious about being viewed as a black party is revealed by two recent, publicly embarrassing incidents. In Florida, D emocrats in the state H ouse of R epresentatives made history by selecting a black, Willie F. L ogan, to be chairman of their caucus. See M ireya Navarro, D emocrats' V ote O pens a Racial Rift in Florida, N.Y. TIM ES, Feb. 8, 1998, at $A$ 14. Their vote placed Logan in line to become Speaker if the party regained control of the House. However, before that promotion would ever come to fruition, the Democratic Caucus replaced Logan with a white woman. While D emocrats maintained that Logan was replaced because he was an ineffective fundraiser, Logan and other black legislators suspected that Florida D emocrats simply were not prepared for a black party leader. See id. The controversy has sent an already beleaguered Florida Democratic Party into a tailspin, but tellingly, "[t]he party erosion and the racial tensions are endemic in the South, where R epublicans have gained ground among whites and D emocrats have become increasingly dependent on blacks." Id.

In Illinois, R oland Burris, also black, appeared to be headed to victory in the Democratic gubernatorial primary. See Pam B elluck, A Front-R unner Fades and Some See Race Playing a Role, N.Y. TIMES, Mar. 13, 1998, at A 13. But Burris' lead began to fade in the midst of calls that he withdraw from the race in order to make the Democratic ticket more racially balanced. If Burris won the Democratic nomination he would likely head a ticket that included U nited States Senator Carol M oseley-B raun, a black woman, and possibly J esse White, also black, who was seeking the $D$ emocratic nomination for secretary of state. See id. B urris lost the primary.

241. See Steven A. Holmes, For Very Strange Bedfellows, Try Redistricting, N.Y. TIMES, J uly 23,1995 , at $A 16$ (reporting that D emocrats want to limit majority-minority districts on the theory that these districts siphon off black voters from moderate white Democratic districts, throwing elections to the Republicans); see also Mark Sherman, Diluting Black Votes for a Stronger Voice, Politicians D ebate Impact of Remap, A TLA NTA J . \& CONST., D ec. 17, 1995, at 3G (noting that many black Democrats favor concentrating blacks in a few districts to help elect more minorities, while white Democrats favor spreading minorities in order to spread their influence). 
majority-minority districts had facilitated their integration into the two-party mainstream.

L et us return for a moment to the hypothetical involving a deal between Georgia Democrats and the New Black and Tan Party to allocate three congressional seats to the latter. It should be apparent that actual black Georgians registered as Democrats who seek a similar deal with their party are effectively acting as a satellite party. But a strict application of the Court's distinction between political and racial gerrymandering would require black Georgians to identify themselves separately from the Democratic Party in order to receive the same fruits as the N ew Black and Tan Party. This creates a perverse and unintended incentive for racial minorities to exit the twoparty system-a system which, the Court has held, states have an important interest in maintaining.

Concededly, the Court could simply treat any alliance between the New Black and Tan Party and the Democrats as impermissibly race-based. The argument would be that a party composed primarily of blacks and identifying its interests primarily with reference to the historical oppression of blacks is, for all intents and purposes, not a political but a racial party. This crude view of race, however, is fraught with analytical deficiencies. Principal among them is the failure to recognize the distinction between a majority-black district, to which voters are assigned, and a majority-black party, with which voters voluntarily choose to affiliate. There can be no stigmatic injury to members of the $\mathrm{N}$ ew Black and Tan Party who constitute a majority in a congressional district created as a result of their party's alliance with D emocrats; these voters voluntarily chose to associate with the $\mathrm{N}$ ew Black and Tans in the first place. A nd the remaining voters in such a congressional district-the "minority" - can no more claim constitutional harm than could the out-numbered Democrats in Davis; they would simply have received the short end of the stick (formal equality) in a model of party participation that assumes someone must. ${ }^{242}$

D ubbing the $\mathrm{N}$ ew B lack and Tan Party a racial party would also leave the impression that the Court is in the business of content control. The Court would be forced to demonstrate that political interests founded on a common history of oppression should be subject to greater scrutiny than political interests based on, say, religious conservatism or opposition to affirmative action or busing. This exercise

242. See supra notes $41-51$ and accompanying text (discussing $D$ avis). 
would place the Court in the presumptuous role of substituting its characterization of a group's political interests for that of the group. $Y$ et, citing First A mendment concerns, the Court has held that "a State, or a court, may not constitutionally substitute its own judgment for that of the Party." ${ }^{243}$

Finally, to deem the New Black and Tan Party a racial party because of its membership's racial homogeneity would be to cast a similar aspersion on the R epublican Party, which is overwhelmingly white, and the Democratic Party in parts of the South, which is increasingly black. ${ }^{244}$ Thus, the Court might reject the New Black and Tan Party as a political party, but in so doing, it would lay bare a set of ahistorical, paternalistic assumptions about politics that could not be applied consistently to other interest groups or political parties.

A lthough influencing the redistricting process is not the sole reason for affiliating with a major party, it is an important one. A s J ustice 0 'Connor put it, "[t]he opportunity to control the drawing of

243. D emocratic Party of U nited States v. W isconsin ex rel. L aF ollette, 450 U .S. 107, 123-24 (1981) (invalidating W isconsin's rule that allowed people who were not members of the D emocratic Party to select delegates to the D emocratic National Convention, contrary to the national party's rules). N otably, the Court in L aF ollette stated:

A political party's choice among the various ways of determining the makeup of a State's delegation to the party's national convention is protected by the Constitution. A nd as is true of all expressions of First A mendment freedoms, the courts may not interfere on the ground that they view a particular expression as unwise or irrational.

Id. at 124 (footnotes omitted). While a First A mendment analysis of the Court's reverse-racial gerrymandering cases is beyond the scope of this A rticle, it would appear that the principles announced in L aFollette apply equally to political parties' determinations regarding diversity among their elected representatives. See James U. Blacksher, D red Scott's U nwon Freedom: The R edistricting Cases as B adges of Slavery, $39 \mathrm{H} \mathrm{ow}$. L.J . 633, 687 (1996). B lacksher argues:

$J$ ust as the right of association of members of a political party is a basic constitutional freedom and ... governmental actions that may have the effect of curtailing freedom to associate is subject to the closest scrutiny, so too should the First A mendment protect the right of black citizens to free political association. Strict judicial scrutiny should be satisfied if the state shows that its race-conscious districting schemes or other electoral structures are the product of genuine negotiations between authentic representatives of the black and nonblack communities.

Id. (internal quotations and footnotes omitted). Cf. M ary T. B oyle, N ote, A ffirmative A ction in the D emocratic Party: A n A nalysis of the E qual D ivision Rule, 7 J .L . \& PoL. 559, 585-86 (1991) (criticizing the Democratic Party's "equal division" rule, providing for equal numbers of male and female delegates to the $D$ emocratic National Convention, because the rule has failed to increase the number of female elected officials).

244. See Grann, supra note 108, at 14 (noting the extreme racial segregation of the major parties). Indeed, on this view of it, a state would be prohibited from affording the $\mathrm{N}$ ew Black and Tan Party a place on the ballot, since state action conferring such a right would be impermissibly race-based and would presumably give rise to the representational harms that $A$ brams is intended to prevent. For a discussion of the inconsistency of such a prohibition with the precepts of liberal democracy, see infra notes 262-265 and accompanying text. 
electoral boundaries through the legislative process of apportionment is a critical and traditional part of politics in the U nited States, and one that plays no small role in fostering active participation in the political parties at every level. ${ }^{245}$ Thus, it is unsurprising that one of the principal motivations for past black efforts to form independent third parties has been the refusal of the major parties to share in the allocation of representational power. ${ }^{246}$

Unlike satellite parties, independent parties are not affiliated with either of the two major parties; they instead seek to successfully compete against them ${ }^{247}$ Post-emancipation black involvement with independent third parties can be traced to the Compromise of 1877, in which President Rutherford B. Hayes agreed to withdraw most federal troops from the South, leaving former slaves vulnerable to restoration of "home rule" by vengeful white southerners. ${ }^{248}$ B ecause neither the Democrats nor the R epublicans embraced black participation at this time, blacks sought allies within the Populist movement. ${ }^{249} \mathrm{In}$ several states, these alliances aided the reelection of blacks who had originally secured their seats during R econstruction. ${ }^{250} \mathrm{H}$ owever, these coalitions collapsed under the weight of Populist demagogues' efforts to further disenfranchise blacks. ${ }^{251}$ B lack efforts to participate in national party politics were largely abandoned until 1900.252

If there are recurring themes in black third party movementswhether independent or satellite - they are that black representation matters to blacks, and that the inability to achieve this end within the

245. D avis v. B andemer, 478 U .S. 109, 145 (O 'Connor, J ., concurring) (emphasis added).

246. See K athryn Flewellen, The National B lack Independent Political Party: Will H istory Repeat?, in 21 FREEDOMWAY S 93, 94 (1981) (noting that "the failure of most white-led political formations (whether D emocrat, R epublican, right-wing, liberal or left) to demonstrate a willingness to share power with Blacks" has been one of the "overriding circumstances" giving rise to black independent political movements).

247. See Walton, Black Political Parties, supra note 31, at 183-87.

248. See id. at 48 .

249. See id. at 50 .

250. See id.

251. See id. Populists, like other third parties of this period, exploited the N egro as a scapegoat for the party's failings at the polls. See id. at 35. Walton writes: "[I ]f the minor party lost, as was generally the case, N egro suffrage was vigorously denounced; the N egro was accused of being a corrupting element and an obstacle to progressive reforms." Id.

252. See id. at 50-51. 
two-party system fuels an impulse to work outside of it. ${ }^{253}$ Thus, James E. Clyburn (now a Democratic Congressman) formed the U nited Citizens' Party in 1969 because white South Carolina Democrats had not rewarded black support of the party by electing blacks to the state legislature. ${ }^{254} \mathrm{~B}$ lacks in A labama have experimented with at least two independent parties, the Lowndes County Freedom O rganization and the $\mathrm{N}$ ational $\mathrm{D}$ emocratic Party of $\mathrm{A}$ labama. The latter met with initial success on the county level, sweeping the elective offices in Greene County, A labama, in 1970. ${ }^{255}$ M ichigan's F reedom N ow Party ran candidates in thirty-nine state elections in 1964 in order to elect more militant blacks and to admonish Democrats and R epublicans that black voters could not be ignored. ${ }^{256}$ The Peace and F reedom Party placed renowned B lack Panther E Idridge Cleaver on

253. See id. at 187. Walton notes that black political parties of both the satellite and independent variety seek "to bring the black man to a position of power within the A merican political system," id., and he argues that "the opportunities which black parties give blacks for selfdetermination and independence in politics ... make[] black parties play such an important role in the new black politics." Id. at 203-04 (emphasis in original). See also E arl O fari, Independent Black Politics: A n O Id Idea, THE BLA CK SCHOLAR, Sept.-O ct. 1984, at 19, 22) (noting the perennial black demand for power-sharing, including that of $\mathrm{H}$ arlem Congressman $\mathrm{A}$ dam Clayton Powell, who insisted, "where we [blacks] are $20 \%$ of the voters, we should command $20 \%$ of the top jobs, $20 \%$ of the judgeships, $20 \%$ of the commissionerships and $20 \%$ of all political appointments").

Professor Lani Guinier's criticisms of black-majority, single-member districts are relevant here. Professor G uinier has argued, in substance, that measuring black electoral success by the number of black representatives elected elevates symbolic representation above interest representation. See LA NI GUINIER, The TYRANnY OF THE MAJORITY $54-55$ (1994). She suggests that majority-minority districts fail to adequately address the issues of legislative influence and coalition-building within prejudiced policymaking bodies. See id. She argues for the use of a system of interest representation in which modified at-large systems would replace single-member districts and voters would possess as many votes as there are open seats. Each voter would be allowed to aggregate his votes as he sees fits, clumping all of his votes on one candidate if he chooses or spreading them across several. See id. at 94-97. Where there is a politically cohesive group of racial minorities, they can vote strategically to elect the candidate(s) of their choice. This arrangement facilitates cross-racial coalition-building because it allows "voluntary constituencies" to self-identify their political interests rather than having those interests artificially imposed on them through geographic districting. See id. at 97.

Professor G uinier's proposal may be one way to reduce the impulse to exit that this A rticle contends A brams v. J ohnson creates. H owever, within the context of the single-member, winner-take-all districts currently in use for congressional elections, a systemic inequality between blacks and whites in their ability to influence the redistricting process cannot lend vitality to the two-party system.

254. SeeWalton, Black Political Parties, supra note 31, at 77.

255. See $\mathrm{H}$ anes Walton, J r. \& William H. Boone, Black Political Parties: A Demographic A nalysis, 5 J. B LACK STUD. 86, 88 (1974).

256. See Walton, Black POLItical PARties, supra note 31, at 198-99. 
the presidential ballots of nearly twenty states in $1968 .^{257}$ A nd throughout the past few decades, black leaders and intelligentsia have gathered together to contemplate formation of an independent black third party. ${ }^{258}$

The defendant-intervenors in Abrams, who urged the Court to show deference to G eorgia's stated preference for at least two black congressional districts, ${ }^{259}$ echoed a decades-long call for power sharing. They maintained that white bloc voting prevented the successful election of black congressmen. ${ }^{260}$ The irony is that blacks' chosen party, the Democrats, heeded their call for power sharing, but the Court did not. From the standpoint of black voters, however, it does not matter that the decision which has prevented their equal participation has come from the Court rather than from the Democratic Party itself. The doctrine of "separate but equal" announced in Plessy v. Ferguson ${ }^{261}$ demonstrates that the Court can be as discriminatory as any state actor. And the unwillingness of Georgia's Democratcontrolled assembly to reenact its plan calling for two black districts on remand from Miller v. Johnson only proves that the Court's heightened scrutiny of black districts may be exploited by the D emocratic Party to whitewash its elected leadership. In effect, then, the Court has positioned itself as a pawn in the tug-of-war for power between black and white D emocrats.

1. D istinctions B etween Black and White Exit. Perhaps a fair-or at least doctrinally consistent-response to the threat of black exodus from the two-party system is a non-response. Political factions, after all, enjoy a right to exit from (and to move within) the two-party system that is fundamental to maintenance of a liberal democracy:

257. See id. at 199.

258. See, e.g., Flewellen, supra note 246, at 100-01 (discussing the meeting of the National Black Independent Political Party convention after the election of Ronald Reagan, which "signaled to Blacks that all the gains of the civil rights movement would come under attack"); $R$ on $D$ aniels, The National B lack Political A ssembly: B uilding Independent B lack Politics in the 1980s, BLACK SCHOLAR, Mar.-A pr. 1980, at 32) (discussing the deliberations of the National B lack Political A ssembly through the 1970 s and 1980s).

259. See A brams v. J ohnson, 117 S. Ct. 1925, 1930 (1997).

260. See id. at 1935-37. The defendant-intervenors in A brams contended that there was substantial racial bloc voting in G eorgia, but the district court rejected their evidence to this effect. See id. While the majority found that the district court's conclusions were not clearly erroneous, J ustice B reyer, in his dissent, noted that of the black representatives in the G eorgia legislature, all except one were elected from predominantly black districts. See id. at 1945 (B reyer, J., dissenting).

261. 163 U .S. 537 (1896). 
"[C]itizens may, of their own volition, move away from other citizens-based on whatever reason they have for moving-and still govern themselves as a public entity." 262 Thus, it is not unconstitutional for the government to grant ballot access to or otherwise to recognize the R epublican Party even though its modern incarnation consists of racially conservative whites who exited the D emocratic Party because of its embrace of racial liberalism. ${ }^{263}$ A s long as membership in the Republican Party continues to be available on a race-neutral basis, the party may constitutionally exercise public power despite its views and the racial homogeneity of its membership. ${ }^{264}$ The same is true of those whites who exit the twoparty system, voting, for example, for G eorge Wallace's A merican Independent Party, ${ }^{265}$ or Ross Perot's Reform Party: ${ }^{266}$ they exit of their own volition, and, no matter what their reasons for exiting, we cannot divest them of political or policy authority simply because of those reasons, or because of the racial composition of the parties for which they vote. Thus, the liberal democratic argument for nonresponse asks: since we have allowed whites to exit freely from the two-party system, why should there be special concern with a black exodus?

The circumstances under which racial minorities would exit the system, however, differ significantly from those under which whites do, particularly after Abrams. First, "A frican-A merican political

262. A bner S. G reene, K iryas J oel and Two M istakes A bout E quality, 96 Co LUM. L. REV. 1, 45 (1996) (discussing problems of exit in the context of nomic-or religious-communities that live apart from mainstream society and seek government aid in the creation of nomicspecific school districts). This A rticle uses the concept of "exit" in a narrower sense than it is used in Professor Greene's discussion. In the context of party politics, we are not concerned with questions of physical separation, though M iller v. J ohnson and the Supreme Court's preoccupation with black districts' shapes indirectly raises issues of spatiality and geography.

263. See supra note 180 (discussing a shift in the R epublican approach to civil rights).

264. See Greene, supra note 262 , at 45 (stating that citizens who successfully move away from other citizens may not "use this public power to exclude on the basis of religion or race ... but if the public power, at least temporarily ... runs in effect to a group homogeneous as to religion or race, then it is wrong to say that the government has 'segregated' or has 'forced separation'").

265. A labama G overnor G eorge Wallace ran on this party's "anti-N egro" platform in the 1968 presidential election, capturing 10 million popular votes and 46 electoral votes. See WALTON, BLACK POLITICA L PARTIES, supra note 31, at 189. Wallace's supporters would later defect to the R epublican Party. See D A w SO N, supra note 101, at 106.

266. Billionaire Ross Perot made a surprisingly strong showing in the 1992 presidential election, capturing nearly $20 \%$ of the popular vote. In 1996, running under the banner of the R eform Party, Perot received only $8 \%$ of the popular vote. See Susan B enkelman, Weakened Perot Faces Future Full of Q uestions, DENVER POST, Nov. 6, 1996, at A 6. 
choice is [unusually] constrained" because black voters almost uniformly support candidates and parties that represent racial reform. ${ }^{267}$ $Y$ et the threat of white exit constrains the degree to which a party or candidate is willing to stand for racial reform. White exit, whether from or within the two-party system, has a capacity to transform a major party-particularly on matters of race-that minorities manifestly lack. The transformation of the Republican Party from the black-supported party of Lincoln to one of racial conservatism attests to the transformative capacity of white movement. By contrast, D emocrats' steady movement to the political center (and at times to the right), reflecting the party's uneasiness with the appearance of being dominated by blacks, evidences the check that the threat of white exit exercises even on the black-supported party. ${ }^{268}$ Thus, even before A brams, black options within the traditional two-party system were severely limited. A brams, however, more drastically differentiates racial groups by imposing on minorities unique disabilities in the apportionment process: white homogeneity is not taken into account in assessing the constitutionality of white voters' demands in the redistricting process, but black homogeneity is weighted prominently. U nder these circumstances, blacks do not enjoy the same right to exit from and within the two-party system as do whites. Blacks' potential exit from the two-party system cannot be viewed as an ordinary exercise of liberal democracy's right to exit. Their actions must instead be viewed as the product of discrimination-more akin to the formation of South Carolina's U nited Citizens' Party than to voluntary disaffiliation.

The constitutional overtones of a black exodus from the twoparty system are also distinct from those of white exit. Since at least City of Richmond v. J.A. Croson C $0 .{ }^{269}$ the Supreme Court's Fourteenth A mendment jurisprudence has been nominally color-blind, rejecting in all but the narrowest of circumstances the concept that we must consider race in order to reduce the salience of race. ${ }^{270} \mathrm{~A}$

267. D A WSON, supra note 101 , at 131.

268. See supra note 240 and accompanying text. See also M ichael J. K larman, B rown, Racial Change, and the Civil Rights M ovement, 80 V A . L. REV. 7, 135-36 (1994) ("[T ]he presidential politics of the 1950s reveals that ... the immediate political imperative of balancing appeals to northern blacks and liberals against those to southern white racial conservatives deterred either party from charting bold new paths on civil rights.").

269. 488 U .S. 469 (1989).

270. See, e.g., id. at 493-94 (affirming that "the standard of review under the Equal Protection Clause is not dependent on the race of those burdened or benefited by a particular classification"); see also A darand Constructors, Inc. v. Pena, 515 U .S. 200, 226, 237 (1995) (subjecting 
black exodus would challenge both the moral and the legal authority of the Court's approach: the Court may insist that states eschew race in redistricting, but in order to take race out of the political process the Court must convince blacks that it ought not be a consideration. A black party would represent the ultimate failure of the Court's efforts, for race would then become more, not less, salient. U nlike other categories of affirmative action, in which blacks are largely a captive audience to the Court's color-blind rhetoric, politics is an arena vulnerable to effective black backlash. The question for the Court is not whether black racial consciousness is a good or bad thing, but how best to accommodate its reality without destroying the fabric of states' two-party political systems and estranging the very groups whose inclusion is essential to the Court's aspiration of a color-blind society.

2. The Practicality and Inertia Factors. Perhaps the Court believes that the possibility of black exodus from the two-party system is too remote to be a serious consideration. Save for a few local parties that continue to field candidates successfully, black third party movements, like white ones, have been relatively unsuccessful. ${ }^{271}$ From the standpoint of doctrinal coherency, however, it ought not matter what the history of black third party movements has been: the Court's ballot-box jurisprudence should be consistent and complementary, encouraging the inclusion of racial minorities in the two-party mainstream to the same extent as whites. Moveover, history may be of limited guidance after A brams v. Johnson. The Court's tolerance of political gerrymandering enables blacks to make demands as a third party which would be constitutionally suspect under A brams were the same goals pursued within the Democratic Party. U nder this state of affairs, the classic arguments against black third parties-that they leave blacks without influence in the political mainstream where policymaking will actually occur-hold considerably less sway. A black third party could operate as an independent party for purposes of redistricting-thus gaining the black seats that A brams would otherwise deny blacks- but act as a

all racial classifications, even purportedly benign classifications, to strict scrutiny, but insisting that this test is not "strict in theory, but fatal in fact") (citations omitted). D espite the Court's precatory statements regarding the continued ability of governments to address the lingering effects of historical discrimination, see id. at 509-10, the Supreme Court has yet to uphold a race-based remedy under strict scrutiny. See Spann, supra note 180, at 22-23 \& nn.104-05.

271. See WALton, BLACK POLITICA PARTIES, supra note 31, at 201. 
satellite party to a major party (presumably the Democrats) within the legislatures to which its members were elected. Interestconvergence would encourage, if not compel, an enfeebled Democratic Party to broker mutually advantageous political compromises with their erstwhile black members. ${ }^{272}$

Past may not be prologue for yet another reason. In A brams and its progeny, the Court for the first time has found in the Constitution unique restrictions on the ability of major parties to respond voluntarily to black aspirations for representation. Previous opinions had addressed racial minorities' efforts to use the Fourteenth and Fifteenth $\mathrm{A}$ mendments and the $\mathrm{V}$ oting $\mathrm{R}$ ights $\mathrm{A}$ ct to impose increased black representation on parties and the localities which they govern. A brams is extraordinary because it restricts racial minorities' ability to use political processes to persuade the major parties of the need for black representation. Given this "first," it is folly to predict cavalierly that a black third party movement will not take root.

E ven if past were prologue, however, history reveals that third parties have played substantial roles in effectuating racial justice, and that blacks have been willing to associate themselves with minor parties for that purpose. In 1840, for example, the abolitionist platform of the Liberty Party helped to rekindle N egro interest in politics and to reignite the Negro "freedom movement." ${ }^{273}$ The Liberty Party would three years later open its national convention to black delegates, providing blacks "with their first opportunity to participate in a political convention." 274 Subsequent abolitionist third parties, the F ree Soilers and the Political A bolition Party, also served to promote the cause of racial justice and to spur black interest and participation. ${ }^{275}$ I ronically, the anti-slavery stances of these parties were popu-

272. See B ell, supra note 174 , at 523 ("The interest of blacks in achieving racial equality will be accommodated only when it converges with the interest of whites.").

273. See Hanes Walton, JR., The Negro in Third Party Politics 12 (1969) [hereinafter WALTON, THIRD PARTY POLITICS]. Walton maintains that despite widespread disenfranchisement among blacks, "it can be assumed that many Negroes did support the political movement." Id. at 11 . In fact, the National Convention of Colored Citizens, which included such black abolitionist luminaries as Frederick D ouglass, later officially endorsed both the principles of the Liberty Party and the party itself. See id. at 13-14.

274. Id. at 14. Several black delegates were appointed to high-ranking positions on various party committees. See id. In addition, the Convention adopted resolutions calling for the equal treatment of black citizens and welcoming them into the ranks of the party. See id.

275. See id. at 18-19. A ttesting to the extent of black involvement in these parties, the Political A bolition Party nominated Frederick D ouglass as its vice presidential candidate in 1856. See id. D ouglass, however, declined the nomination. See id. 
larized in 1856 and 1860 by the most famous and enduring of all A merican third parties, the Republican Party. ${ }^{276}$ The Republican Party displaced the Whig Party as one of the two major political parties in the $U$ nited States. ${ }^{277}$

Third parties' advocacy of racial justice and blacks' resultant embrace of such parties are not limited to so-called "constitutional moments" ${ }^{278}$ like the slavery crisis. For instance, the activities of the Progressive Citizens of A merica in 1948 furthered the civil rights agenda of black A mericans. ${ }^{279}$ While he was ultimately not able to carry the black vote or to win the presidency, the party's nominee, Henry Wallace, campaigned vigorously for black equality, posing a substantial risk that black Democrats would bolt from the Democratic Party. ${ }^{280}$ This threat apparently aided a "shift in attitude and policy by [President Harry S.] Truman," which in turn "caused a political shift in the Negro community." 281 In short, when mainstream avenues for political participation have been unavailable, blacks have embraced minor parties to advance the cause of racial justice, at least until the major parties were willing to be equally responsive. ${ }^{282}$

A s long as blacks themselves view black representation as a significant indicator of racial justice, the Supreme Court's restrictions on the ability of the major parties to afford such representation to their black constituencies will remain starkly at odds with the Court's and the states' desire for two-party political stability.

\footnotetext{
276. See id. at 20.

277. See id. at 1.

278. "Constitutional moments" is Professor B ruce A ckerman's name for periods of A merican history, such as the advent of the $\mathrm{N}$ ew $\mathrm{D}$ eal, that occur outside the realm of normal politics and that effectively reinterpret, or amend, the Constitution outside the restrictions of $A$ rticle $V$. See B ruce A . A ckerman, The Storrs L ectures: D iscovering the Constitution, 93 Y A LE L.J . 1013, 1022, 1054-56 (1984).

279. See WALTON, ThIRd PARTY Politics, supra note 273 , at 80.

280. See id. at 56-58.

281. Id. at 59. Specifically, President Truman submitted his civil rights proposals to Congress and established a Committee on Equality of Treatment and Opportunity in the A rmed Services and a Fair Employment Practice Board. See id. at 58. President Truman forwarded these initiatives at the urging of a close advisor who had calculated that the black vote in northern cities might well decide the election. See KINDER \& SANDERS, supra note 180, at 199.
}

282. See WALTON, THIRD PARTY POLITICS, supra note 273 , at 81 . Walton writes:

[T ] hird parties have at various times given the N egro the opportunity to become vocal on the race issue, when the major parties had side-stepped or dropped the issue. However, when faced with bigger and better opportunities for agitation and the chance to continue to remind the nation of the N egro's plight, N egroes have not hesitated to leave the smaller third parties.

Id. 
3. The Shifting Political E nvironment. A s the twenty-first century nears, blacks must participate in a changing political environment, and this environment may work in combination with the forces outlined above to fragment racially the two-party system. Some of the transformations are uniform in their impact-they do not uniquely relate to race. For instance, billionaire Ross Perot's two presidential bids and the formation of the Reform Party have augmented the prospects for a successful third major party that would not necessarily revolve around minority issues. ${ }^{283}$ Furthermore, the continued dealignment of the electorate (the deterioration of voter identification with either of the two major parties) ${ }^{284}$ poses a risk to two-party stability independent of black protest.

There has also been a general rightward shift in the A merican political context-a turn of events that creates a unique impetus to exit for racial minorities. D uring the twelve years of the presidencies of R onald Reagan and George Bush, the political context of black participation was unfavorably altered. ${ }^{285}$ R eagan's ascendancy to the presidency in 1980 began the rollback of the advancements made during the civil rights era. ${ }^{286}$ Noting Reagan's desire to appeal to southern racial conservatives, political scientist $\mathrm{H}$ anes Walton, J r., concludes:

By reintroducing racial cleavages for partisan gain, the $R$ eagan- $B$ ush R epublicans turned the anger, resentment, and frustration of whites to their own partisan advantage.

A frican A mericans' efforts to attain their civil rights were reconstructed as a zero-sum game in which whites were the losers. Problems in the nation's A frican A merican-governed urban areas became acute, and the hard-fought constitutional attainments of the preceding decades were put into jeopardy. Forward motion on the unfinished agenda of the civil rights movement was stalled while A f-

283. See J oseph E. H aviland, Recent D ecisions, Timmons v. T win Cities A rea N ew Party, 36 DU Q. L. REV . 207, 224 (1997).

284. See supra note 8.

285. See $\mathrm{H}$ anes Walton, J r., Prospects, in A fRICAN A Merican Power and Politics: The Politica l CONTEXT VA RIA Ble 369, 370-71 (R obert Y. Shapiro ed., 1997).

286. See $\mathrm{H}$ anes Walton, Jr. \& William O. G enerett, J r., A frican A mericans, Political Context, and The Clinton Presidency: The L egacy of the Past in the Future, in A FRICA N A MERICAN POWER AND POLITICS, supra note 285, at 373, 373-74. 
rican A mericans and their civil rights allies engaged in damage control to maintain some degree of stability. ${ }^{287}$

W hile estranged from the R epublicans, blacks have been unable to look optimistically to the D emocratic Party, which has been forced by the "R eagan-B ush contextual revolution" to drift from its historical commitment to assisting blacks. ${ }^{288}$ Indeed, the Democratic Party of the 1990s "has moved to the right of center." ${ }^{289}$ These shifts render it "easier for mainstream A frican A merican voters to consider thirdparty candidates in lieu of their traditional affinity for Democratic party candidates." ${ }^{290}$

Thus, the effect of A brams v. Johnson does not occur in a vacuum but rather in a political environment in which voter loyalty generally, and black voter fealty specifically, are already strained. A ballot-box rule that fuels party infidelity among blacks (particularly when there is no tangible injury to whites' right to vote) is a doctrine fundamentally at odds with the notion of two-party political stability. Moreover, it is stunningly inappropriate to allow the reverse-racial gerrymandering decisions to exact their greatest toll on the bulwarks of the two-party system: black voters are the most reliable Democratic partisans in A merica. ${ }^{291} \mathrm{~A}$ rational two-party paradigm, one that is consistent with the principles of Davis v. Bandemer, would permit the major parties to reward their most loyal adherents in the most important partisan process-redistricting.

\section{THE CROSSROAdSOF TIMMONSAND A BRAMS: GREATER INSTA BILITY?}

The Court's evident discomfort with both minor parties' and black voters' efforts to participate in the two-party process is not coincidental. Rather, it reveals a consistent misapprehension of the constitutional injury asserted by the plaintiffs in both the third party

287. Id. at 374 .

288. Id. at 375 .

289. H anes Walton, J r., A frican A mericans and The Clinton Presidency: Political A ppointments as Social J ustice, in A FRICA N A MERICA N POWER AND POLITICS, supra note 285, at 313, 322; see also D ana M ilbank, Party Crashers, NEW REPUBLIC, J une 15, 1998, at 21, 23 (noting that the D emocratic Party has drifted right and characterizing its recruits for the 1998 congressional elections as follows: "[S]ome of these $\mathrm{N}$ ew D emocrats sound so much like R epublicans that it's not very clear why they aren't R epublicans in the first place." ).

290. See Walton \& G enerett, supra note 286 , at 375 .

291. See David Lublin, The Paradox of Representation: Racial GerrymanDERING AND M INORITY INTERESTS IN CONGRESS 59 (1997). 
cases and the reverse-racial gerrymandering cases. This section first explicates this parallel, and then demonstrates its practical effect on two-party stability.

\section{A. The D eference-Injury N exus: A Second L ook}

R ecall the argument made in Part III that the Court's recognition of the injuries in Shaw and A brams marked a departure from its prior ballot-box cases, which required, as a threshold matter, that the plaintiffs had suffered an injury to voting. ${ }^{292}$ The Court in Abrams presumed a constitutional injury ${ }^{293}$ en route to subjecting the formation of two of Georgia's majority-minority districts to strict scrutiny. ${ }^{294}$ In Timmons, there was no need for a presumption: the Court acknowledged that Minnesota's anti-fusion law prevented the $\mathrm{New}$ Party from nominating its chosen candidate. ${ }^{295} \mathrm{Y}$ et the Court minimized this quite tangible injury in order to avoid applying strict scrutiny. The Court achieved this result by judicial sleight of hand: it declined to apply strict scrutiny because the injury to the $\mathrm{N}$ ew Party was not "severe," but it failed to point to any antecedent definition of severity. ${ }^{296} \mathrm{H}$ aving concluded that the burdens imposed by M innesota's anti-fusion ban "though not trivial," were "not severe," the Court required $\mathrm{M}$ innesota to present regulatory interests "sufficiently weighty to justify the limitation." ${ }^{297}$ G iven that the state was not required to present empirical evidence to meet its burden, ${ }^{298}$ this test, too, begged

292. See supra notes $204-215$ and accompanying text.

293. See supra notes $189-200$ and accompanying text (discussing the lack of a constitutional injury in recent racial gerrymandering cases).

294. See A brams v. J ohnson, 117 S. Ct. 1925, 1931 (1997) (noting that strict scrutiny is the appropriate standard of review where, as in this case, race is "the predominant factor in constructing the ... [d]istrict").

295. See Timmons v. T win Cities A rea N ew Party, 117 S. Ct. 1364, 1372 (1997).

296. See id. at 1372. The Court was content to supply a laundry list of restrictions that the anti-fusion ban did not impose on the New Party-the ban did not "restrict the ability of the New Party and its members to endorse, support, or vote for anyone they like," nor did it "directly limit the Party's access to the ballot." Id. B ut while it is certain that M innesota could have attempted to impose more severe restrictions on the $\mathrm{N}$ ew Party, the party may nevertheless have suffered substantial injury by not being allowed to nominate the candidate of its choice.

297. Id. (quoting N orman v. R eed, 502 U .S. 279, 288-89 (1992)).

298. See id. 
a definitional question: what renders a justification "sufficiently weighty" ? ${ }^{299}$

A fter Shaw v. Reno and its progeny, however, doctrinal consistency would seem to dictate that the kind of injury suffered by the New Party would warrant application of heightened constitutional scrutiny. The plaintiffs in Timmons at least suffered a tangible injury related to voting. By contrast, the plaintiffs in Abrams were allowed to proceed based on broad notions of stigma, an immeasurable harm which they might have suffered with or without government action. Deprivation of the ability to nominate the candidate of one's choice is a limitation uniquely related to the government's ability to control the electoral machinery of the state. The Court cannot reasonably recognize a "representational" harm in its racial gerrymandering cases but ignore the actual representational injury to the $\mathrm{New}$ Party. ${ }^{300}$

It can, of course, be argued that there is nothing extraordinary about the Court's differing treatments of injury in the two cases: the Court in A brams was more solicitous of the plaintiffs' injury because it concluded that Georgia's majority-minority districts divided voters by race. But the "race is different" argument fails in this instance. The Court's application of strict scrutiny in Abrams actually disadvantaged black participation in the two-party process. Similarly, its application of a lesser standard of review in Timmons disproportionately harmed racial minorities because these groups constituted such a large share of the $\mathrm{New}$ Party's membership. ${ }^{301}$ Of course, disparate impact alone may not transform the N ew Party's claim into one of racial discrimination in violation of the $\mathrm{E}$ qual Protection Clause of the Fourteenth A mendment. ${ }^{302}$ There is, however, an analytical tension in employing strict scrutiny to restrict black participation in the twoparty system in one case, only to employ a lesser standard of scrutiny

299. See Pope, supra note 30 , at 480 (referring to the Court's test as "Iudicrously circular on its face" but acknowledging that it does signal greater deference to the state than strict scrutiny).

300. Cf. Foster, supra note 179, at 1172 (characterizing the right to a color-blind electoral process as not "as weighty as impediments to the right to vote").

301. A s argued throughout this A rticle, in view of A brams, minorities may come to constitute a disproportionate share of the third party movement generally. See supra Parts II and III.

302. See Washington v. Davis, 426 U .S. 229, 242 (1976) ("[W ]e have not held that a law, neutral on its face and serving ends otherwise within the power of government to pursue, is invalid under the Equal Protection Clause simply because it may affect a greater proportion of one race than of another."). 
in another case to again restrict black participation. ${ }^{303} \mathrm{M}$ oreover, after the Shaw v. Reno line of cases, it is far from clear that the disparate impact on minority voters' opportunity to nominate the candidate of their choice would not violate the Equal Protection Clause. By applying strict scrutiny in the absence of a specific intent to harm an identifiable group in its reverse-racial gerrymandering cases, ${ }^{304}$ the Court may have opened the door to a similar relaxation of the trigger for heightened scrutiny in other contexts, including cases like Timmons. ${ }^{305}$

D espite the appropriateness of recognizing the New Party's injury as substantial in view of the latitude afforded by its racial gerrymandering decisions, the Court in Timmons demurred. The Court's comfort with entrenched interests suggested in the comparison between Timmons and Tashjian ${ }^{306}$ thus becomes more apparent in aligning the plaintiffs' injuries in Timmons and Abrams, for in both of the latter cases white voters (another entrenched interest) were better served by the Court's holding than were racial minorities. The Court's misapprehension of the plaintiffs' alleged injuries also has consequences for the very definition of political stability which it has openly embraced, for in each case the Court either overlooked or incorrectly analyzed the state's interest in the maintenance of stable two-party government. ${ }^{307}$ Thus, the nexus between deference to states' political interests and the Court's assessment of injury is a fairly consistent one. A Ithough Timmons posed this equation in the more familiar formalism versus protective democracy context of

303. The factual differences between A brams and Timmons do not lessen this absurdity. A ssume that instead of the N ew Party, the plaintiffs in Timmons were the $\mathrm{N}$ ew B lack and Tan Party. J ust as black voters in A brams sought to participate in the political process as black voters, members of the N ew Black and Tan Party, as a black party, would seek to co-nominate the D emocratic candidate. $Y$ et G eorgia's attempt to integrate black voters into the two-party political mainstream triggered strict scrutiny while Minnesota's efforts to block this same result would prompt a far more deferential standard of review.

304. See F oster, supra note 179, at 1161-63.

305. Even under traditional, pre-Shaw equal protection analysis, state action which systematically deprives minority voters of the ability to forge coalitions to nominate their preferred candidate may well abridge the Fourteenth $A$ mendment's prohibition against racial discrimination. See Washington, 426 U.S. at 242 ("[A ]n invidious discriminatory purpose may often be inferred from the totality of the relevant facts, including the fact, if it is true, that the law bears more heavily on one race than another."). This scenario could happen, if, over time, racial bloc voting within the major parties in combination with state anti-fusion bans consistently prevent minorities from nominating the candidates of their choice.

306. See supra notes 73-79 and accompanying text.

307. See supra notes 73-79 and accompanying text. 
Davis v. Bandemer, its ramifications are fundamentally linked to A brams' deprivation of minimal formal equality for black voters in the traditional two-party system.

\section{$B$. The $M$ aking of $O$ utcasts}

W hile A brams renders it more difficult for racial minorities to participate on an equal basis in the "critical and traditional" ${ }^{308}$ party activity of redistricting, Timmons erects a barrier to their engaging in the relatively nontraditional partisan activity of fusion. ${ }^{309} \mathrm{Y}$ et the deprivation of traditional means often leads to the adoption of untraditional ones. In fusion, as in satellite politics, dissenting voices are given a place within the two-party structure without submerging their individual political identities. The suggestion here is not that fusion is the same as operating as a satellite party-it is not. H owever, fusion fits well within the spectrum of activities tied to the two-party system-from registering with the Democrats or R epublicans to not formally affiliating but voting at the invitation of these parties. The Supreme Court's treatment of it as alien strongly resembles its treatment of black G eorgians' satellite-type activity in A brams. The Court

308. D avis v. B andemer, 478 U .S. 109, 145 (O 'Connor, J ., concurring)

309. Fusion is untraditional in the sense that most states now bar it. See Timmons, $117 \mathrm{~S}$. Ct. at 1369 n.6 (noting that in the twentieth century fusion has been limited and is now barred in most states). Thirteen states expressly prohibit fusion candidacies. See G A. CODE A N N. § 21-2137 (1993); 10 ILL. COMP. STA T. § 5/7-12(9) (West 1993); IND. CODE § 3-10-1-15 (1993); KAN. StA T. A NN. § 25-213 (1993); KY. REV. STA T. A NN. § 118.335 (Banks-Baldwin 1998); L A. REV. STAT. A NN. § 18:1280.25 (West Supp. 1998) (banning fusion in presidential primaries); MINN. StA T. § 204B.06(1)(b) (1992); M O. ReV. StA T. § 115.351 (1997); NeB. ReV. StA T. § 32-612(3) (1997); 25 PA. Cons. StA T. A NN. § 2870 (West 1994); TENN. COdE A NN. § 2-5-101(f)(1) (Supp. 1997); TEX. EleC. CODE A NN. § 162.015(a)(2) (West Supp. 1998); WIS. STA T. A NN. § 8.15(7) (West 1996).

Twenty states and the $D$ istrict of Columbia effectively prohibit fusion by requiring that $a$ candidate be a registered member of the party whose nomination he seeks. See A LA. CODE $\S \S$ 17-16-12, 17-16-14 (1995); A LA SKA STA T. § 15.25.030(14) (1996); A RIZ. ReV. STA T. A NN. § 16311(A) (West 1996); CAL. ELEC. CODE § 8022(a) (West 1996); Colo. REV. STA T. A NN. § 1-4601(2) (West 1997); D.C. COdE A NN. § 1-1312(a)(1)(A), (r)(1)-(2) (1981 \& Supp. 1998); FLA. STA T. ch. 99.021(1)(b) (Supp. 1998); H A W. REV. STA T. § 12-3(a)(7) (1995); ME. REV. STAT. ANN. tit. 21-A, § 334 (West 1993); MD. ANN. CODE art. 33, § 4A-1(a) (1997); MASS. GEN. LA WS. ch. 53, § 48 (1990); NEV. REV. STA T. § 293.177 (1997); N.H. REV. STA T. A NN. § 655:14 (1996); N.J. STAT. ANN. § 19:23-5 (West 1989); N.M. STAT. ANN. §§ 1-8-2, 1-8-18 (Michie 1995); OHIO ReV. Code A nN. § 3513.07 (West 1994); O KLA. StA T. tit. 26, § 5-105 (1997); R.I. GEN. LA WS § 17-14-1 (1996); W. VA. CODE § 3-5-7 (Supp. 1998); WY O. STA T. A NN. § 22-5-204 (M ichie 1997).

Four states achieve a ban on fusion by permitting a candidate to accept only one nomination. See IOWA CODE A NN. § 49.39 (West 1991); MICH. COMP. LA WS $\S 168.692$ (1989); M ONT. COdE ANn. § 13-10-303 (1997); N.D. CEnT. CODE § 16.1-12-06 (1997). 
undervalued the kinds of party activity most conducive to the inclusion of racial minorities in each case because it asked the wrong question. In A brams, the question was not whether the Second and Eleventh Congressional $D$ istricts were drawn on grounds of race; instead, the appropriate inquiry was whether the confluence of interests and processes that led to the creation of those districts were any different from those endorsed by Justice $O^{\prime} C$ onnor's concurrence in $D$ avis $v$. $B$ andemer. A nd in Timmons, the simple issue should have been whether fusion can rationally be categorized as a major-party activity. Since it clearly can be, and since the activity was welcomed by the major party, the state's burden should have been heavy indeed. ${ }^{310}$

Let us return a final time to the hypothetical travails of the $\mathrm{New}$ Black and Tan Party. Recall that their agreement with Georgia $D$ emocrats is that they will be given the two additional congressional seats that $\mathrm{A}$ brams denied them if $\mathrm{N}$ ew B lack and T an Party members pledge support for the Democrats' statewide candidates. ${ }^{311}$ B ut what form will this support take? While New Black and Tan members might simply vote for the Democrats' candidate on the Democratic line of the ballot, this would hurt the status of their party. Like most states, G eorgia bans multi-party or fusion candidacies. ${ }^{312} \mathrm{~A}$ t the same time, in order to constitute a "political party" in G eorgia, an organization's candidate must have garnered at least $20 \%$ of the statewide vote in the preceding gubernatorial or presidential election. ${ }^{313} \mathrm{~A}$ failure to satisfy this threshold showing would relegate the New Black and Tan Party to the status of "political body." ${ }^{314} \mathrm{~A}$ s such, the party would be subject to numerous restrictions not applicable to political parties, including a requirement that it obtain the signatures of $5 \%$ of the eligible voters for each office it sought in order to place its candi-

310. In this regard, the Court's inability to appreciate the different ways in which voters might choose to participate in the two-party system bodes poorly for two-party stability no matter what the racial composition of the minor party. It is clear that the Court's view of majorparty activity, and hence its definition of two-party stability, is a static one that fails to consider how the growing dealignment of the electorate might lead voters to affiliate with the two major parties in different ways, such as through fusion.

311. See supra notes $96-108$ and accompanying text.

312. See GA. CODE A NN. § 21-2-137 (1993) (stating that a candidate may not "qualify with any political party as a candidate for nomination to any public office when such person has qualified for the same primary with another political party").

313. See id. § 21-2-2 (Supp. 1998).

314. Id. This discussion assumes that $\mathrm{N}$ ew B lack and Tans are otherwise able to satisfy the $20 \%$ threshold. This is a reasonable supposition: in the hypothetical described in Part II.A., most of G eorgia's $28 \%$ black population belong to the party. See supra text accompanying note 102. 
date on the ballot. ${ }^{315}$ If fusion were allowed, the Democratic candidate could appear on the ballot twice-once as a D emocrat, once as the New Black and Tan candidate-and the New Black and Tan Party could support the Democratic nominee for governor without sacrificing its status as a political party because its votes could be disaggregated from the total votes received by the Democratic nominee..$^{316}$ The H obson's choice presented in the Georgia scenario could repeat itself in each of the other states in which the Supreme Court has struck down majority-minority congressional districts. ${ }^{317}$

Whether the N ew Black and Tan Party decides to adhere to the deal and subject itself to the more restrictive requirements of minorparty status will depend on its cost-benefit analysis, but its decision is less important than the doctrinal morass which imposes that choice on it in the first place. It is odd enough that in the name of racial harmony A brams promotes the making of deals between Democrats and putative third parties that would be impermissible between white and black D emocrats. But it is positively bizarre that under the guise of political stability Timmons threatens to break those deals and encourage separatism over coalition-building.

315. See GA. CODE ANN. § 21-2-170(b) (Supp. 1998) (requiring that the nomination petition for a candidate in a non-statewide race be signed by " 5 percent of the total number of registered voters eligible to vote in the last election"). See also M cCrary v. Poythress, 638 F.2d 1308, 1310-11 (5th Cir. 1981) (upholding constitutionality of G eorgia's 5\% requirement).

316. But see Note, Fusion Candidacies, Disaggregation, and Freedom of Association, 109 HARV. L. REV . 1302, 1305 (1996) (distinguishing fusion from disaggregation while noting that the latter is often implicit in the former). The note explains:

A Ithough disaggregation does not change which candidate wins an election, whether a state that allows fusion must disaggregate the votes of multiparty nominees is a critical issue .... [U ]nless there is a formal method by which votes are attributed to the minor party, the party will be unable to satisfy the ballot access or ballot status provisions that condition political opportunity on some quantum of electoral support.

Id. (emphasis omitted).

317. For example, Texas, where Bush v. Vera, 517 U .S. 952 (1996), arose, forbids fusion. See Tex. Elec. Code Ann. § 162.015 (West Supp. 1998). It also conditions political party status upon the number of votes received in statewide general elections, see id. $\S 181.005$ (requiring $5 \%$ in order to qualify as a major party), and imposes signature requirements on organizations not achieving the requisite votes. See id. $\S 142.007$. North Carolina, home to the landmark wrongful districting decision Shaw v. Reno, 509 U .S. 630 (1993), bans fusion by requiring that the candidate be registered with the party for whom she is nominated. See N.C. GEN. STA T. § 163-106(b) (1995). Like G eorgia, it conditions major-party status on the number of votes obtained in the last preceding gubernatorial or presidential election. See id. § 163-96(a) (imposing a $10 \%$ threshold). M inor parties must satisfy petition procedures in order to nominate a candidate. See id. § 163-96(b). 


\section{CONCLUSION}

B aldwin's dilemma ${ }^{318}$ is alive and festering. The Supreme Court's continuing failure to address race in politics by acknowledging the realities of race will continue to fracture political processes, possibly to a point of racial splintering of the two-party system. A t some point, whether by collision or conscience, the Supreme Court will have to face the fact that the concept of political stability so loosely employed in Timmons has a racial dimension applicable in redistricting cases as well. If, as Abrams reaffirms, the state infringes upon a citizen's guarantee to equal protection of the laws by intentionally separating electoral units along racial lines, it must be free to discourage the formation of effectively segregated political parties. $\mathrm{H}$ istory and logic dictate that this task will require allowing the major parties to negotiate power-sharing arrangements with the constituents of those parties regardless of whether the result is a majority-minority district. The Supreme Court's two-party stability rationale has modern justification when viewed not merely as a protection against the multiplication of minor parties but rather as a guard against splinter coalitions which contravene the color-blind ideals of A brams.

In this regard, Baldwin issued an admonition about the A merican racial dilemma that both the Court and voters might do well to heed:

E verything now, we must assume, is in our hands; we have no right to assume otherwise. If we-and now I mean the relatively conscious whites and the relatively conscious blacks, who must, like lovers, insist on, or create, the consciousness of the others-do not falter in our duty now, we may be able, handful that we are, to end the racial nightmare, and achieve our country, and change the history of the world. If we do not now dare everything, the fulfillment of that prophecy, re-created from the Bible in song by a slave, is upon us: God gave Noah the rainbow sign, No more water, the fire next time! ${ }^{319}$

318. See supra notes 1-3 and accompanying text.

319. James BaldWin, The Fire Next Time 119-20 (Dial Press 1963) (1962). 